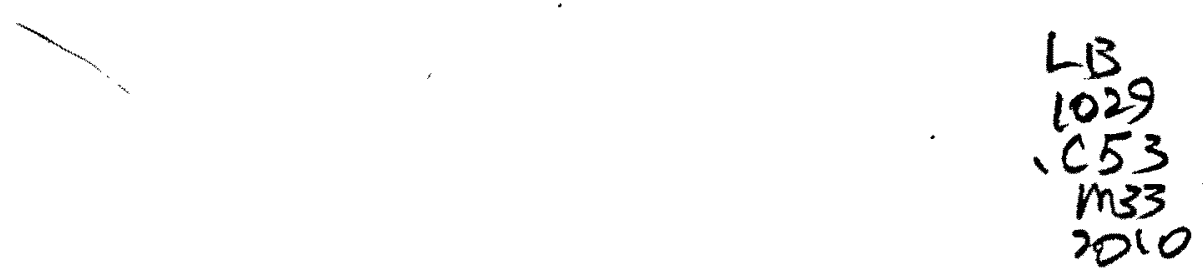

NARRATIVES AS REFLECTIVE PRACTICE IN MULTI-AGE CHILD CARE CENTRES

\author{
By \\ Jean MacDonald \\ Bachelor of Applied Arts, \\ Early Childhood Studies \\ Ryerson University \\ Toronto, Ontario 1998
}

\author{
A Major Research Paper \\ Presented to Ryerson University \\ In partial fulfillment of the \\ requirements for the degree of \\ Master of Arts \\ in the Program of : \\ Early Childhood Studies
}

.Toronto, Ontario, Canada, 2010

(c) Jean MacDonald 2010 
I hereby declare that I am the sole author of this major research paper.

I authorize Ryerson University to lend this major research paper to other institutions or individuals for the purpose of scholarly research.

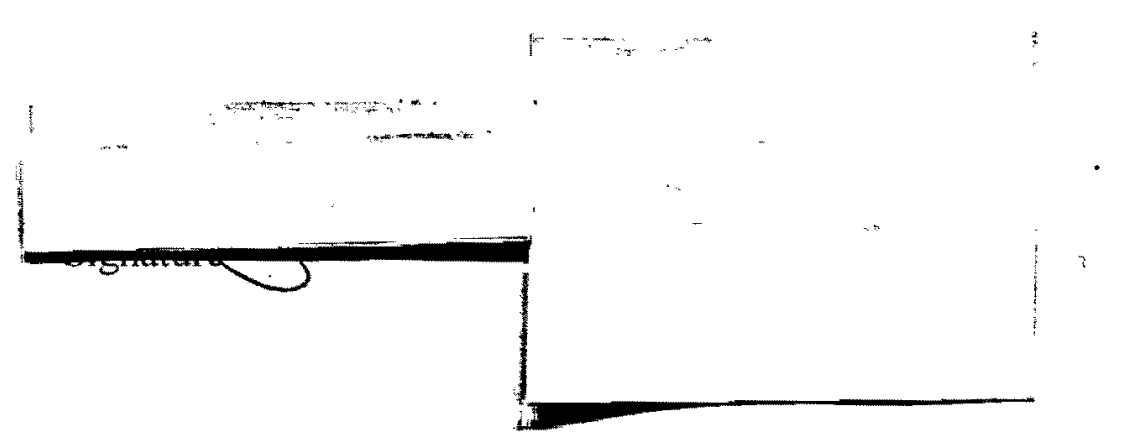

I further authorize Ryerson University to reproduce this major research paper by photocopying or by other means, in total or in part, at the request of other institutions or individuals for the purpose of scholarly research.

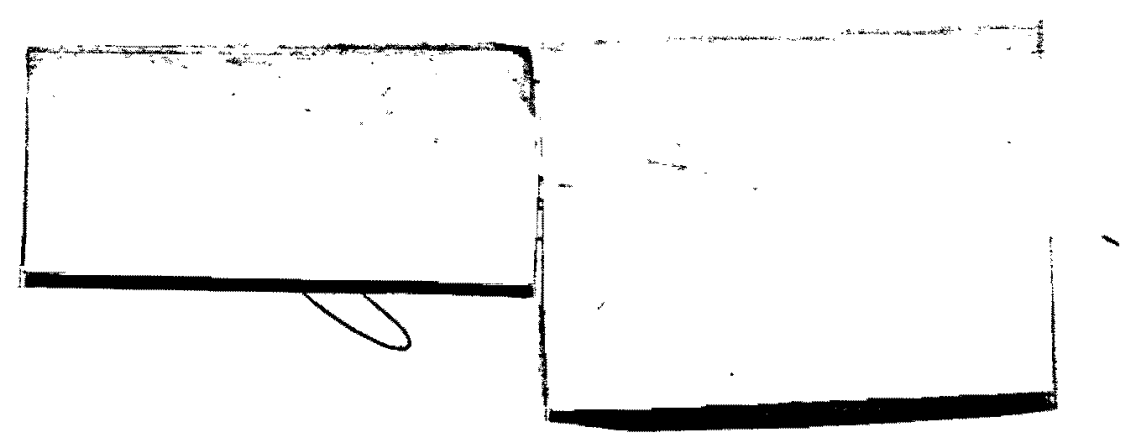




\title{
NARRATIVES AS REFLECTIVE PRACTICE IN MULTI-AGE CHILD CARE CENTRES
}

(C) Jean MacDonald, 2010

Master of Arts Early

Childhood Studies

Ryerson University

\begin{abstract}
This study used narrative inquiry to collect the stories of educators working in a multiage setting. Interviews with five staff from two centres in Ontario and one in British Columbia yielded six rich narratives. Some of the themes that emerged from the findings were 1) Perceived Preparedness 2) Experience in the field and 3) Development of a Professional Philosophy. The results of this study support the value of narratives as a tool for professional practice, peer collaboration and reflective practice.
\end{abstract}

Keywords: Multi-age; Child care; Narrative Inquiry, Post modernism; Reflective Practice; Professional Philosophy 


\section{Acknowledgements}

My sincerest gratitude goes to my supervisor, Dr. Elaine Frankel for her guidance, encouragement and rich knowledge base. Your constant encouragement has brought me to this point and I could not have done it without you.

My sincerest gratitude also goes out to my second reader, Dr. Patricia Corson. You were the first one to introduce me to multiage settings in my undergraduate degree. Your excitement and passion made me believe in its possibilities too.

To Dr. Rachel Langford, for helping me to better understand the post modern framework. Your contributions were invaluable. 


\section{Dedications}

To my mother and father, for giving us all the greatest gift one can ever have - family. Your sacrifices have not gone unnoticed and you've always made us feel like the most important thing in your lives.

To my mom and my best friend - we did it! Thank you for supporting me every step of the way through this adventure and every adventure in life. You are my rock. Thank you for looking after everything so that I could commit time and energy to this process. I love you.

To my dad and my hero, you inspire me every day. Thank you for always sharing your strength with us. You are a remarkable gift. Thank you for teaching me that life is about learning and that it never stops.

To Guy, my strength and support, you've been with me on this journey since the beginning. Thank you for allowing me the time to focus on it and for making this a priority in both of our lives. Thanks for always saying it's okay to just stay home and work or just stay home and sleep, if that's what I needed that day. It's time to start our journey together now.

To the crew of 8 - thank you for letting Auntie work on her paper, even if that sometimes meant I couldn't play. Button - the 'big paper' is done, let's party!

To the many fellow MAECS students that supported me through the last two years. I think "book club" was as much a part of the journey as any class. To Deborah, my therapist, who helped me to always keep things in perspective. I take comfort in your words; "Remember to breathe and be you - that is more than enough." 


\section{Table of Contents}

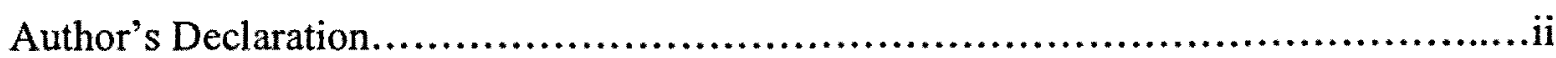

Abstract.........................................................................

Acknowledgements................................................................

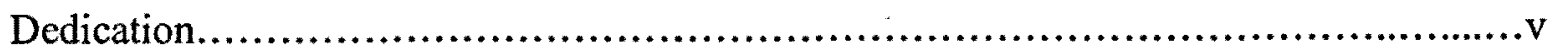

Table of Contents........................................................................vi-vii

List of Appendices.....................................................................

Chapter 1: Introduction......................................................... 4

Chapter 2: Literature Review................................................ 5 - 14

Chapter 3: Methodology....................................................... 15 - 17

Participants.......................................................... 18

Interviews.................................................... $19-20$

Data Analysis..................................................20 - 21

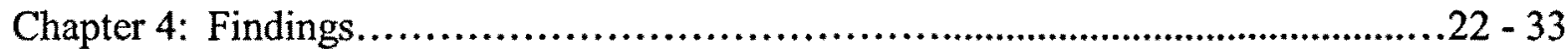

Chapter 5: Discussion.............................................................. 44

Chapter 6: The narratives....................................................45-67

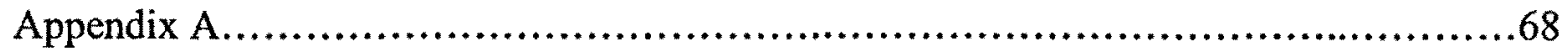


Appendix B.................................................................... 69 - 71

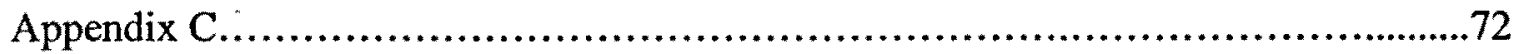

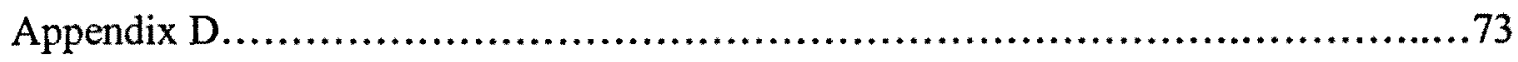

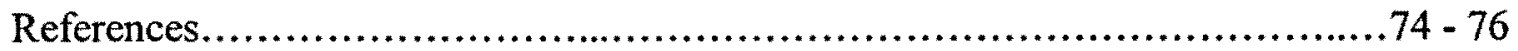




\section{List of Appendices}

Appendix A. Recruitment Flyer

Appendix B. Consent Agreement

Appendix C. Interview Guidelines - Interview \# 1

Appendix D. Interview Guidelines - Interview \# 2 


\section{Introduction}

There is no single definition of family, particularly in the post-modern era. In this paper, "family" is defined by The Vanier Institute of the Family as: "any combination of two or more persons who are bound together over time by ties of mutual consent, birth and/or adoption or placement and who, together, assume responsibilities for variant combination of some of the following: physical maintenance and care of group members; socialization of children; social control of members; affective nurturance - love."(Family, n.d.).

The benefits that can be experienced from a family are important for all, but it is particularly crucial for young children (Pettit, Dodge \& Brown, 1988). The family unit can be a place where children develop their identity, learn to socialize, create a cultural context and understand the world around them. Noddings (1986) states that families are the origin of children's sense of caring. In families we learn what it means to be cared for and, in turn, how to care for others. "The relation of natural caring is the human condition that we, consciously or unconsciously, perceive as "good". It is that condition toward which we long and strive, and it is our longing for caring - to be in that special relationship - that provides us the motivation to be moral" (p. 5). "Post modern research seeks to deconstruct the hegemonic nature of the discourse of family and to illuminate the embedded power structures that define families and that directly affect the lives of young children" (Spodek \& Saracho, 2006, pg 520).

Families exist across every culture. In Canada, our social policy allows a parent to be home with their newborn child for up to a maximum of one year with paid benefits. After that year, the majority of children enter into childcare, spending an ever increasing amount of their day away from the potential benefits of a family structure. Despite the fact that in 1990, Canada became one of the 80 nations to sign the United Nations Convention on the Rights of the Child, 
it still does not have a universal system of childcare. Friendly (1991) states "childcare (in Canada) has developed in a haphazard manner driven by market forces, with regional inhibition and facilitation and community initiatives directing development of services" (p.7).

The most prevalent model of child care in Ontario is one where children are grouped by age. The Day Nurseries Act divides children into groups of infants (ages newborn to 17 months), toddlers (18 -30 months), preschoolers ( 30 months up to 5 years of age), kindergarten (5-6 years) and school age ( $6-12$ years).

Another model of care licensed under Ontario's Day Nurseries Act is multiage groupings. In multiage childcare groupings, early childhood educators work with children, ranging in age from newborn to age 12 all within the same room, over the course of a number of years simulating the experience and potential benefits of developing in a family unit. The intention is that by mirroring the bonds of a family unit within a childcare setting, children are able to develop and maintain the benefits of a family structure. This model may offer the opportunity for children to support each other emotionally, physically and mentally, while creating goals and a cultural framework which is mutually beneficial to all members.

The legislation for childcare in British Columbia was different than that of Ontario's. In 2007 a new provincial child care licensing regulation was introduced in British Columbia. The changes were as follows:

- Family child care operators will now have the flexibility to take in a maximum of seven children, newborn to five years, without having to reserve spaces for infants and school-age children. This will leave more spaces for toddlers and pre-school age children.

- A new category of child care licensing-Multi-Age Child Care - will allow eight children in a home with one ECE-certified individual, an increase from seven children under the Family Child Care category.

- New ECE graduates will be given one-year certificates to work as fully qualified staff immediately upon graduation. Child care operators will have additional qualified staff to draw from when hiring, and new graduates can 
get their required 500 hours of work experience needed for full licensing (Ministry of Children and Family Development, 2007).

These changes resulted in the increase in the number of centres and homes operating in a multiage model.

Novick (1996) discusses the importance of moving away from child care grouped by age since "children live increasingly in an age-segregated society, in child care and schools and spend less time with families and in neighborhoods, which include a range of ages" (p. 6). In addition, families' lives have become separated from each other through childcare, school and work and therefore there is a diminished capacity for all members of the family to create shared meaning and understanding. Novick (1996) states, "Creating a community of learners, in which all members see themselves as both teachers and learners, enables children, teachers, and families to develop shared understanding about what is important to know and why it is important" (p. 5).

Although there has been significant research indicating how multi-age grouping childcare does simulate the strengths of family settings, (Corson \& Martin, 2000; Evangelou, 1989; Kolstad \& McFadden, 1998) the overwhelming majority of child care centres still use the traditional peer grouped structure as their model of care. With all of the known benefits that exist for children and families in multiage settings, such as continuity of care, development of social competency and scaffolded learning, why are there so few centres operating with this model?

To examine the change in teacher practice towards a multiage model, this study collected and examined teachers' narratives about their own work in multi age settings. Narrative inquiry is a qualitative tool for gathering information about a person's story. In 2007, Hinyard \& Kreuter define the narrative as "any cohesive and coherent story with an identifiable beginning, middle, 
and end that provides information about scene, characters, and conflict; raises unanswered questions or unresolved conflict; and provides resolution"(p.778).

The narratives enabled educators to reflect on their work and training and to use their reflections as an impetus for change. Participants in the study identified what assisted them in making the change from a more standard model of child care to a multiage setting and how their own philosophy was altered as a result. Their rich narratives are also useful to guide the practice for future ECE students who will one day be educators in the field.

This research sought to answer two key questions:

1. What factors assisted participants in making the change from a more standard model of child care to a multi-age setting?

2. How did their own narrative assist them in altering their philosophy? 


\section{Literature Review}

Corson \& Martin (2000) define "multiage groupings" as, "the placement of children of different ages together in activity and learning areas for substantial portions of the daily schedule"(p. 2). The intention of multiage groupings is to emphasize the goal of using teaching and curriculum practices that maximize the benefits of interaction and cooperation among children of various ages. In multiage settings, children are given the opportunity to learn from peers, to exchange ideas, to develop their own knowledge and to build community learners.

In the modern era childcare settings grouped children of similar ages together based on the Piagetian belief that children learned at the same developmental rate at the same chronological time, (otherwise known as age and stage theory) (Gonzalez-Mena, 2009). Post modern views of development on the other hand propose that children develop emotionally, socially and cognitively at very different rates (Lubeck, S. 1996). It sees development not as linear, but as occurring and adapting over time. Post-modernism also supports the notion of plurality, questioning issues of universality in development, the idea of knowledge, what makes best practices, and the role of education in caring for children. Many children are socialized in part by both their family and their day-care provider. With this in mind, a multiage framework is the model most similar to a family unit, thereby minimizing the variance in children's

environments. Multiage settings can be a quality model of child care that supports the needs of some families.

This study uses a post modern theoretical framework because it allows for the construction of knowledge through diverse perspectives. "Post modernism has such features as the challenging of convention, the mixing of styles, tolerance of ambiguity, emphasis on - 
diversity, acceptance (indeed celebration) of innovation and change, and stress on the constructedness of reality" (Beck, 1993, p. 1).

Post modern views on children's growth and development require us to examine the basic assumptions of early education. Constructivist thinkers such as Bandura, Rousseau, and Dewey would agree that "knowers" not only construct their own knowledge, but that interaction with each other leads to common understandings. In 1978 one of the founders of the constructivist perspective, Len Vygotsky, (as cited in Gonzalez-Mena \& Windmer, 2008) introduced a sociocultural theory which includes two important terms "zone of proximal development"-(ZPD) and "scaffolding". The ZPD refers to the idea that a child's level of potential development is enhanced by more capable peers. Constructivists contend children learn bi-laterally from each other and gain new behaviours and competencies by observing and imitating others (GonzalezMena, 2009). Scaffolding refers to a teacher or peer offering assistance to the child through which shared negotiation, brainstorming, problem-solving and engagement in the activity, assists the child in developing new knowledge. Vygotsky's definitions lay the foundation for supporting a multiage settings approach and the perceived benefits for cognitive, social and emotional growth for children.

As a child, even though I attended a typical grade school with traditional classrooms in which children were divided by their age, my educational experience was not defined in that way, but rather in the way we were educated at home. As a practice, each day after dinner all five of the siblings and my parents would bring out their homework and work on it together. Whenever anyone had a question about their work, we all stopped and listened to the problem. Instead of simply providing the answer, my parents would ask us to summarize the topic and then the question was put out to the siblings to see if anyone knew the answer. If so, that child 
would explain the information and start a dialogue amongst everyone else, almost as the facilitator of group learning. What makes this process unique is that there was an age difference of almost ten years from youngest to oldest. It happened at times where the youngest was learning words for a grade one spelling test and would be paused to participate in learning the matters of grade eleven chemistry. Nothing was considered too advanced, nothing too simplistic because after all, it was not about the content of the subject, but rather about the context of learning. It was engrained in us that learning was a social endeavour and it was supported by the benefits of interaction and cooperation. Scaffolding learning, peer teaching, acting as a role model and sharing the balance of intellectual power were all enormous lessons learned as a result of this daily exercise. If you were the child with information to offer, you were empowered by facilitating other's learning and if you were the one seeking knowledge, you felt part of the group process of discovering meaning for yourself as part of a community. Proponents of the post modern perspective (Spodeck \& Saracho, 2006) suggest that while a family can support children's development, the benefits of family can also be replicated in a multiage setting childcare.

A significant number of multiage group models currently exist within early childhood settings. Many home childcare, Montessori schools, family resource programs and Ontario Early Years Centre all work within family style settings which serve a variety of age groups. These settings work to support the benefits of family groupings, but in addition they provide a very practical benefit to multiage groupings as well. In peer-grouped childcare there is a significant portion of the day dealing directly with the physical needs of the children including feeding, diapering, dressing, particularly during the years before age three. Though the time spent on physical needs is theoretically an opportunity to bond and develop trust between adult and child, 
due to the large number of children and the limited time schedule and constraints on staff, these become mechanical processes to simply complete a task. In multiage groupings, the ratios dictate fewer toddlers in each room thereby reducing the amount of physical care required by staff. This provides the opportunity to develop a trust and bonding relationship with staff and children during routine care experiences.

Aina (2001) states multiage settings help children to recognize that learning is life long and it is socially constructed by all members of the community (p.226). Multiage groupings value all knowledge and therefore remove the hierarchical sense of power created in traditional school systems where learning comes only from teachers and is given to students. Multiage settings value a sharing of power, of knowledge construction and a shared learning experience across the community.

One of the key components of education questioned by post modern thinkers is the notion of binary thinking. Pacini-Ketchabaw \& Pence (2005) state, "In ECE, we discuss the distinctions between included and excluded, appropriate and inappropriate, as being natural. However, these distinctions are contingent upon dualistic conceptions of power and, as such, they are problematic" (p. 8). Multiage groupings work to diminish this power issue and instead create a community of learners where each has shared roles, power, responsibility, and right to discourse. In multiage groupings children hold their own power as they are able to deal with the information presented to them on their own schedule, in their own way, through their own strengths. They are not compared to their same age peers as either understanding the curriculum or not in an age specific time and therefore have more of a sense of individual internal power and strength, since power is not based on comparison and relativism with peers. 
Aina (2001) supports this notion as she describes her observation in teaching in a multiage classroom noting children are more interested in cooperating with each other than defining who is capable of doing something and who isn't. She focuses on the importance of children's perception of their own ability to learn as a tool to assess their capacity to learn and believes the way children feel about themselves and their sense of competence in learning impacts every learning act. Children cannot simply be given knowledge, they must construct it for themselves and this learning is contingent on social interaction. Through sharing their learning with others, children not only support the community sense of shared understanding, but they broaden their understanding as well. Without the support of the teacher and his/her acceptance of these beliefs, the children will not be given the opportunity to create this learning experience for themselves:

Post modernism forces us to reexamine education as something other than the traditional 'banking model' of education (Friere, 2000) where the teacher is the giver of knowledge and the child is the recipient. In multiage settings, children and teachers create shared knowledge as they are given the opportunity to learn from peers, exchange ideas, develop their own knowledge and build community learners. Gmitrova \& Gmitrov (2003) examined the cognitive competence of kindergarten children in both teacher-directed and child-directed pretend play. The authors explain "it is more likely that pretend play engages many areas of the brain because it involves emotion, cognition, language, and sensorimotor actions, and thus it may promote the development of dense synaptic connections" (p. 244). Findings show a significant positive effect of mixed-age groupings on children's pro-social behaviour and cognition. One of the strengths of multiage groupings is the extended period of time in which these children remain in groups together and therefore deepen their social relationships. The opportunity to interact with children 
both older and younger increases children's intellectual development as they have to modify the way in which they interact with children of various ages.

The average classroom encompasses children who have a huge variety of skills levels across the curriculum including those with special needs, giftedness and other students who are ill served by the current educational classroom. Tomlinson (2004) cautions against labeling children simply because they have "failed to perform in classrooms according to expectations"( $p$. 517). He states the labels are damaging as it suggests that the learner is flawed and not the system itself. Understanding that children develop at different rates, the multiage model is perfect for allowing development to take place naturally, without identifying deficits of the child. Multiage settings benefit the less advanced student by allowing him/her to teach younger students some of the skills he/she has already mastered and thereby gain confidence in his/her abilities. Tomlinson (2004) speaks of multiage settings as the opportunity to explore diversity such as special needs, cultural and language in a positive light.

Current educational philosophy focuses on differentiated instruction as an effective means of educating children. This involves providing opportunities in the learning environment that support learners of all strengths in different ways. Due to the natural variance in age and skill levels in multiage settings, differentiated instruction is a naturally occurring phenomenon. Key to the success of this model however is the role of the teacher. Although it may seem the teacher's role in a multiage setting requires much more work, data from Hoffman (2003) revealed that teachers in multiage classrooms are not expected to do anything more than regular classroom teachers in terms of dealing with "differentiated instruction, flexible grouping, social collaboration, student choice and adaptive curriculum"(p. 11), they are just dealing with it on a wider range of skill levels. The success of the classroom was heavily dependant on the beliefs 
and practices of the teacher including their ability to create and adapt curriculum, as well as their willingness to access other resources.

For this reason, it is critical to explore teacher's perceptions of multiage groupings and to examine how they impact the classroom structure. The findings presented by Aina (2001) show the difficulties teachers perceive about multiage settings are "primarily of a logistical nature" (p. 221). The concerns include issues of space, equipment, policies for outings and grading measures. She believes all of these issues can be supported through better teacher training, as well as appropriate communication with parents and administrators

The benefits to children educated in multiage groupings are not necessarily seen academically. In fact "research has found few, if any, differences in academic achievement for most children in graded and non-graded classrooms" (Novick, 1996, p. 2). In a study of nine, ten, and eleven year olds, Gerrard (2005) found there was "no significant correlation between multiage groupings and student's math and reading skills, however a difference did occur in language skills, greater levels of creativity, group cooperation, and problem solving"(p. 247). Gerard (2005) states "the construction of knowledge is a social endeavor. For children, learning and academic achievement is done together" (p. 248). Although the benefits of multiage settings are not defined strictly academically, they are defined by the goals of developing the whole learner. The benefits include, but are not limited to self-regulation, positive social emotional relationships, leadership building, empathy, discourse and more individualized attention.

Critical to the success of multiage settings is how the teacher involves him/herself in the children's learning experience. Teachers need to create opportunities for children to interact with more advanced and less advanced peers, and strengthen their cognitive skills while still keeping within their individual rate of knowledge and skill acquisition. There is a decided lack of 
research on multiage groups in early childhood settings since the level of cognitive growth is harder to measure, but the benefit of increased cognitive competency and opportunity for children to be both leamer and facilitator benefit their social competency. Without the opportunity of being in a family-like setting with children of various ages, children miss the opportunity to feel a sense of belonging, confidence, self-assurance, autonomy and the possibility to gain competency skills by assisting others.

Two major criticisms of a multiage model have been proposed. 'First, (Gmitrova \& Gmitrov, 2003) is the possibility of regression by older children and secondly (Hoffman, 2003) is the concern about addressing the learners' educational needs in such a wide level of abilities. Those concerned with multiage settings as not meeting the diverse education needs of children may simply be limited in their concept of what true learning is. In a peer grouped classroom, children as well as teachers are all too aware of variances in other's emotional, social and cognitive variations. In fact in same age settings, the one to one comparison between children is obvious. In this model, children can be highly aware of other's diverse learning needs. As there is an expectation of "sameness" in peer-grouped settings, any variance from the norm may be obvious and can result in negative consequences from peers. In multiage settings, the variances are natural and assumed and therefore allow less opportunity for direct comparison amongst teachers and fellow students.

The following studies offer insight into peer vs. multiage group elementary classroom settings. While this is not the main area of interest for this research, the current literature is largely confined to an elementary school age group of children. The relevant issues are quite different than that of an early childhood setting. "Further investigation is necessary to understand teachers' perceptions of the values of early childhood multiage settings. 
Kolstad and McFadden (1998) state there is some resistance to multiage groupings by parents, teachers and administrators, with one study showing "more than half of the principals questioned reported the parents were unhappy with the multiage grouping regardless of how well their child performed in the classroom"(p. 18). Parents felt their older children were not being challenged academically and perhaps the curriculum was being watered down so that it was manageable by students of all ages. Teachers commented that it was significantly more work planning and preparing the classroom for multiage learners, as opposed to a straight grade one class. They said they felt ill prepared and they lacked training. Again, this criticism is dependant on the modern view of success where knowledge is gained via the banking model of education.

The factors that influence success in multiage settings are numerous and need to be addressed by parents, students, children, and administrators alike. "Parents in particular want to know the benefits to their child. Will my child learn more or less?" (Aina, 2001, p. 223). As for the children; "diversity is the key among learners and diversity is the key in creating multiage programs and their curriculum that encourage children to learn independent learning, problem solving, empowerment, and responsibility for their own learning" (Aina, 2001, p. 223). Teachers would need to be open to the wealth of learning potential in a multiage setting that is not strictly defined by academic or curriculum pursuits. Education and information would be a positive step in helping redefine their notion of successful learners. In addition, successful multiage programs "require care, implementation, and maintenance. Planning time, flexibility, practical training, and an ongoing communication plan are just a few crucial areas" (Aina, 2001, p. 223). With the support of administrators, education can assist in stripping away the power filled, educator driven approach to learning information and developing learners. 
While there are clear and evident values to proceeding with multiage settings in educational settings, change does take time. The key to its success is the full and thorough understanding of all participants involved. It takes time to reshape how we view education, success and knowledge and it requires work on everyone's part. Involving teachers, parents and community in the educational change process helps to work towards that change, to building understanding and support for our learners. 


\section{Methodology}

A narrative approach was used to gather information on the experience of educators working in a multiage setting. Narrative inquiry is the process of gathering information for the purpose of research through storytelling. "Humans are storytelling organisms who, individually and collectively, lead storied lives. Thus, the study of narrative is the study of the ways humans experience the world. Research is a collaborative document, a mutually constructed story out of the lives of both researcher and participant" (Conle, C., 2003, p.6).

As a tool for research, narrative inquiry has numerous benefits to the story teller. Narratives become a tool through which educators can examine their own perspectives, make meaning of their experiences and act on these experiences to create future change. This telling of one's own story allows the teller to "structure the way we act in the present, and can guide our future practices" (Ali, Corson \& Frankel, 2009, p. 28). The process of reflective practice is important not only for the decisions educators make in the moment, but also for the choices they make in the future.

In-service providers can develop a broader sense of their own role in a professional setting. They may reflect upon their own experience and consciously make decisions supported by their own reflective practice. Narratives allow in-service providers a model from which to develop their own thoughts/reflections on work with multiage groupings. Beck (1993) states "postmodernism does not represent a single point of view"(p. 3) and narratives allow a diverse perspective. The narrative can be a starting point from which professional development with other staff can occur. Guskey (2002) reminds us "High-quality professional development is a central component in nearly every modern proposal for improving education" (p. 381). Previous models believed that professional development centred on changing teacher's beliefs in the 
workshop were actually quite ineffective. Guskey proposes a new model of how change occurs. It starts with the professional development which is brought into the classroom, the change in student learning outcomes develops and as a result of this there is change in teacher's beliefs and attitudes. Essentially it states people have to live their experiences and see the change in themselves and in others first hand in order to accept the change. Using narratives, either your own or others, can serve as the spring board from which to experience change. The complex process emphasizes how change is dependant upon one's own reflection.

The development of a professional philosophy is so much richer when it can be related to one's own personal experience. "There is a shift from a focus on general information toward the personal and particular, which in turn opens the way for understanding alternative ways of knowing and doing" (Clandinin, 2007, p. 63). An educator trained in the academic components of multiage groupings only holds the theoretical piece of the puzzle until she lives the experience. At that point there is a change from mere curriculum and theory to an understanding, and from that a possible divergence towards other means of supporting children and families. Conle (2003) states the connection between teachers, subject matter and social contexts, at first, appear as separate entities. Through the practice of narratives however these can all be grasped together and "become more complex; but they also potentially become more personally meaningful and socially relevant. Curricular complexity and meaningfulness result from connections to life and quest-like inquiry experiences" (Conle, 2003, p.8).

Narrative inquiry benefits not only the teller, but the listeners as well. In this instance the scope of "listener" extends beyond just the researcher and includes future readers of the research. Pre-service teachers, in-service professionals and professors are just a few examples of those that may experience change as a result of another's narrative. Ali et al. (2009) state "the use of . 
family narratives in the classroom can provide students with insights into lives of families that may be very different from their own. It could help them see these families in a more holistic way rather than in their essentialized categories..." (p. 54).

The narratives of in-service professionals may benefit pre-service teachers as they can gain real-life examples of staff working in multiage settings. Pre-service teachers learn through the real life experience of narratives, viewing the information as more than just a collection of theory and jargon in the classroom that may seem un-relatable. According to Ali et al. (2009), $\cdots$ university and/or college professors can use rich, honest, relevant narratives to bring life to the classroom. Narratives bring a reminder to students that we work with real people, with real families, with real lives, each with their own stories. Conle (2003) reminds us that real cases, seen through narratives, can serve as the beginning of discussions on important key issues and give students the real-world acquisition of key concepts in our learning.

Ali et al. (2009) state "Narratives are also a mechanism for creating dialogue that could illuminate diverse perspectives on the same issue" (p. 28). In childcare there isn't much discussion, but perhaps through narratives a broader understanding of the model can be understood. Narratives may help individuals discuss their perspectives on this issue.

Through narrative inquiry, the researcher them self is changed in the process of gathering narratives. As Conle (2003) notes, "a better understanding of his or her practice is a personal learning outcome for the teacher involved in action research and may bring about major changes in his or her knowledge" (p.11). The consequence of this change improves the professional life of the researcher and continues to develop the breadth of her own experience. 


\section{Participants}

\section{Recruitment Process}

Two multiage settings in Ontario and one in British Columbia were contacted via email. A flyer was sent to the director outlining the purpose, process and potential results of the study (see Appendix A). Interested participants contacted the researcher via phone or email, were screened for eligibility and interviews were scheduled. Eligibility required that participants had graduated from an accredited educational facility, had a minimum of one year experience working in the field, and continued to work in multiage settings.

\section{Participants}

Narratives were constructed from six separate participants. The following table outlines their professional role as well as their years of experience in a multiage setting.

\begin{tabular}{|l|l|l|c|}
\hline & Title & Province & $\begin{array}{l}\text { Years of } \\
\text { Experience }\end{array}$ \\
\hline Participant \#1 & $\begin{array}{l}\text { Supervisor, } \\
\text { Home Child Care }\end{array}$ & Ontario & 22 years \\
\hline Participant \#2 & $\begin{array}{l}\text { Home Visitor, } \\
\text { Home Child Care }\end{array}$ & Ontario & 10 years \\
\hline Participant \#3 & $\begin{array}{l}\text { Owner, } \\
\text { Child care Site }\end{array}$ & Ontario & 24 years \\
\hline Participant \#4 & $\begin{array}{l}\text { Manager, } \\
\text { Childcare Site }\end{array}$ & Ontario & 20 years \\
\hline Participant \#5 & $\begin{array}{l}\text { ECE } \\
\text { Childcare Site }\end{array}$ & Ontario & 1 years \\
\hline Participant \#6 & $\begin{array}{l}\text { Owner/Manager } \\
\text { Childcare Site }\end{array}$ & British Columbia & 4 years \\
\hline
\end{tabular}

The multiage settings included two independently owned and operated childcare sites, one in Ontario, one in British Columbia. The other was an Ontario based home childcare agency. The owners of both childcare centres were interviewed, as was the manager and one 
staff from the Ontario child care site. The manager and one staff from the home childcare agency were also interviewed. The participants' experience in multiage settings ranged from one year to over 24 years.

\section{Interviews}

Six participants were interviewed on two separate occasions. The five Ontario interviews were face to face, but due to restrictions in distance and time, the British Columbia interview was conducted over the phone. Before beginning, participants signed informed consent forms reminding them of their ability to withdraw from the study at any point without consequence. (see Appendix B)

The first interview (see Appendix C) focused on the participant's general views of multiage settings as a framework for childcare, in terms of how they felt it worked for children, families and staff. Their educational training, number of years in the field and their professional role in the centre was discussed. The second interview (see Appendix D) asked participants to reflect on their own practice as educators and whether or not it had been altered as a result of working in a multiage setting. Participants were asked to reflect on how pre-service early childhood educators might be better supported and prepared for work in a multiage setting. The questions asked in the interviews allowed the researcher a framework to initiate a discussion and follow up questions were asked in order to further investigate certain concepts.

All interviews were audio recorded, transcribed and reviewed by participants at each stage to ensure accuracy. From the transcriptions, major themes were identified and a narrative was written summarizing the story of each participants' experience in multiage settings including years of experience, work history and their individual story. Member checks on the narratives 
were completed by the participants and any changes noted were made by the researcher. The final narratives were given to participants for two weeks at which point the researcher contacted them by phone or email to ask two follow up questions. How did your narrative help inform your practice? Did you choose to share your narrative with others and what were the results?

In order to maximize confidentiality, all names of the participants were kept confidential. Upon completion of the transcription of both interviews, participants were assigned fictious names. All data was tracked using a checklist and was securely stored.

\section{Data Analysis}

After each interview, data was transcribed onto a word processing document.

Participants were able to review the transcription and elaborate or clarify their original responses to ensure accuracy. From the interviews, a narrative of each participants experience was created and returned to them to determine accuracy. So as not to leave out information or create themes based on the researcher's own biases, peer referencing was used. The transcribed interviews and subsequent narratives were reviewed by a colleague to ensure trustworthy analysis.

Data coding helped view the data in a more meaningful way. The transcriptions were coded first with free codes, then axial and selective codes as outlined in Neuman (2006) in order to develop pattern and concepts into more refined themes. From the first read of the data free codes were identified. Free codes are "critical terms, central people, key events or themes" (Neuman,2006, p. 461). An example of a free code evident in the data occurs when participants discuss the nurturing that occurs amongst children in multiage settings; 
"I think probably the biggest benefit is the older kids really take on the role of the um nurturing role um. They love to help the little ones and that makes them feel really important right?"

The second pass through the data was to find axial codes or connections among themes represented. An example of an axial code was the linking of themes of nurturing, peer teaching, and sibling support into the code entitled "benefits of multiage settings".

The final pass through the data helps to identify selective codes as you "look selectively for cases that illustrate themes and make comparisons and contrasts after most or all data collection is complete" (Neuman, 2006, p. 464). An example of a selective code was linking benefits, challenges and uniqueness of the model into the larger theme 'experience in the field'. In this research the selective codes were identified as perceived preparedness, experience in the field and development of a professional philosophy.

Additional review of transcripts, in conjunction with theoretical foundations from the known literature, broadened and enriched the themes allowing additional interpretations to emerge.

Three major themes that emerged from the narratives were:

1) Perceived Preparedness

2) Experience in the field

3) Development of a Professional Philosophy 


\section{Findings}

\section{Educational Training}

With the exception of the recent graduate, all Ontario participants said that throughout their educational training they were completely unaware of the model of multiage settings and only unintentionally did they come to work in the model. The response from the recent Ontario graduate was very different, stating she felt prepared and well trained for work, not only in a multiage setting, but in many other models of care as well. The British Columbia participant sought out additional training when new legislation and funding was introduced in 2007 . The legislation allowed for childcare operators to group children in family or multiage settings as opposed to strictly peer-grouped settings. The government offered increased financial support to licensed child care providers converting to this family model.

Despite the variation in participants' location, experience and professional role, three major themes common to all participants emerged from the narratives.

1) PERCEIVED PREPAREDNESS

2) EXPERIENCE IN THE FIELD

3) DEVELOPMENT OF A PROFESSIONAL PHILOSOPHY

\section{Perceived Preparedness}

As a result of their educational training, participants felt largely unprepared for work in a multiage setting. With the lack of formal training, they stated their learning happened only after they had started working in a multiage setting. 
I really had no idea. I was quite ignorant going into this whole scope of home childcare. I had heard of schools that used the alternative, multiage age groupings but I had no idea what I was getting into when I started. It was a definite learning curve this first year. (Manager, Home Childcare, 22 years)

The recent graduate, who previously stated she was well trained in multiage settings through her College, stated that much of her knowledge around multiage settings was learned, not from school, but as a result of assisting her mother in operating a multiage setting home-daycare.

It might be because I've been with kids since I was about 2. My mother ran a daycare for 9 years.

\section{In her home?}

Yes, I've been around kids and daycare all my life so I knew everything about having mixed ages.

Were you able to see your mother model way to work with multiage groups?

Oh definitely, that's why I'm here today. For sure. (ECE, Child care site, 1 year)

Regardless training, education, experience or years in the field, each mentioned the desire for additional, on-going training around multiage settings and new developments in the field of ECE. When asked what type of support the field of ECE could offer, participants responded as follows;

Training on meeting differing needs throughout each day would be great. Training in programming that draws interest and encourages growth in the whole group - infants, toddlers, preschoolers, and beyond. Information on how to prepare the learning environment for a multi-age setting would be greatly beneficial ... how to arrange furniture and create spaces that will meet everyone's needs and inspire creativity and exploration. (Owner/Operator, BC Child care site, 4 years)

I think we would all benefit from having additional training after we are in the field. If there was some type of guideline instruction or course you could take, to give suggestions for throughout the day or something like that. It could help us a lot right, but there isn't right? Which is kind of sad. (Manager, Home Child care 22 years) 
I think not just about this type of setting, but I definitely think there should be a refresher course for anyone who has been out of the field for more than a few years. Even if you are in the field you need updating. I really believe that. That's what we did in nursing. I think we should do the same thing, update the day care act, those things. (Owner, Childcare site, 24 years)

\section{Experience in the field}

\section{Uniqueness of model}

All participants noted that multiage settings are unique and distinct enough from peergrouped care that it warranted specific training for students. Participants felt work in a multiage setting was not the same as taking the components of a peer-grouped centre and putting the pieces together like a puzzle to make the multiage model. Among the differences are social development of children, curriculum, behaviour management, the role of the ECE and the benefits for children and families.

Provide programs and training that are not distinctly separate such as it is now with Early Childhood (3-5) and Infant Toddler (0-3) training. It is often presumed that merging what is learned in each program will be productive in a multi-age setting but it requires a lot more than that to smoothly run a program with such a range in ages. (Owner/Operator, BC Child care site, 4 years)

There are specifics that happen in multiage settings that don't happen in other centres. Our training is all compartmentalized - no one put it all together. You have to test all of your skills in multiage setting all at once-behaviour guidance, curriculum, all of it.(Manager, Child care site, 20 years)

...really, it warrants its own course. You need to be able to address curriculum, behaviour management, it's a completely different thing. You can't take what... well you can take what you.....it's different expectations...the way everything plays out is not the same. It's not like putting it together like a puzzle.(Manager, Home Child care, 22 years) 
There are many challenges working with a multi-age setting. Meeting the needs of the whole group requires a lot more conscious effort than working with a group of children at the same developmental level (Owner/Operator, BC Child care site, 4 years)

As a result of their lack of formal training, participants felt it was not until they worked in the setting that they began to understand the differences of a multiage model.

You are dealing with a completely different environment of largely people who are not trained and then these groupings that didn't make sense in the experience I had had. I really had to change. At first I had almost a negative opinion of it because I couldn't see the benefits of it...It wasn't until I saw the benefits and see how much kids have changed and grown...I had to get rid of the centre snobbish side of me and say 'you have to embrace it'. It was neat but it was so foreign, I was totally unprepared. (Manager, Home Child care, 22 years)

Participants stated a strong, reliable team approach amongst staff was necessary for making the multiage model work.

The three I had here just clicked, they just had to look at each other and they knew what to do. They really worked well, it makes such a difference. It all went so smoothly then. (Owner, Childcare site, 24 years)

Well its diff because having three other teachers in room, I mean it would be different, but there are four of us and four personalities and children bond better with different people. I think having different teachers in the room with you... We are 8 to 1 , but are all in the room together and so if you need to do something, the other teacher can step in.(Manager, Child care site, 20 years)

Especially in our field, it's really hands on training. They don't come out with any sort of base of what they can expect so I can tell them ....but until you actually shadow visits, you don't have any idea what to expect. Our new staff was really smart and she didn't feel comfortable doing it on her own so she was very verbal about it, a lot more than I was, and she asked to keep shadowing until she got it. (Manager, Home Child care, 22 years) 


\section{Benefits}

The benefits of multiage setting for children, staff and families are unique to the model and are not seen in peer grouped settings. Some of the benefits for children include the opportunity for children to nurture, act as role models, support and teach each other.

The younger children are eager observers and the older children are eager helpers and teachers. I strongly feel that children are their own best teachers and when you can put a group together that can offer so much to each other, it's a very positive experience. (Owner/Operator, BC Childcare site, 4 years)

I think probably the biggest benefit is the older kids really take on the role of the um nurturing role um. They love to help the little ones and that makes them feel really important right? I mean the younger kids, with just being around them and language for sure right. That's a definite bonus (pause) I guess in all facets really. When they're sitting and doing creative, just cause the older ones are able to print, starting to print, then they model for the younger ones. I think it works out really well. (Manager, Child care site, 20 years)

If providers do their job well, and put the behaviour management in place, they can use that too and say, no no you're not supposed to do that, look at what so and so is doing and use them to model. Even small children see that on their own and will try to be like the older children saying I will sit here and scribble in the book because he's doing their homework. It's a visual model. (Manger, Home Childcare site, 22 years)

The older children also obtain so much from being a "teacher". They are more aware of their actions and very proud to be involved in milestones reached by younger children. When my son began walking, they cheered, "We taught him that! He watched us! We showed him! (Owner/Operator, BC Childcare site, 4 years)

Another benefit mentioned was the similarity of a multiage setting to that of a family model.

Participants found that children were most comfortable playing with their own siblings,

regardless of the age difference between them:

"I think too why parents like it is it's a family setting, family style and you hear that over and over again." (Owner, Child care site, 24 years) 
Absolutely, you see the siblings spending time together in the setting? For sure.

There's been several right now. We have these two sisters and the little one takes part, basically only playing with the older children. But yeah, you don't find the kids separate or say you can't play kind of thing, they include... I mean there are times I should say, but generally they are accepting of that. (Manager, Child care site, 20 years)

According to the participants, the relationship children had with their siblings was particularly critical at stressful times.

We have another boy and a girl that just started. He used to come here and now his sister is coming and now they're quite close (laugh), they're together and he's always watching out for her and if she gets hurt, she will go first to her brother of course and same with $\mathrm{M}$ and $\mathrm{H}$, they do the same thing, $\mathrm{M}$ will go to her sister and she's really the "mother" you know. The older ones take on the nurturing. (Owner, Child care site, 24 years)

Yes, the bonding element is different only because they are able to be with other family members. It makes it easier for them to come together. (Manager, Home Childcare site, 22 years)

The structure of a 'family model' seemed to offer the same benefits to children who were not related, as one participant tells us:

I think also, they bond to the older kids even if they are not siblings. They like to take care of the younger ones. (Owner, Child care site, 24 years)

Many of the participants mentioned that multiage models provided the opportunity for peer learning;

When kids are building for example or playing the younger ones say, 'I want to build something like them' or 'I want to draw just like them' and that can be good and bad too b/c you want them to have their own unique way of doing things, but the odd things like they will talk like them or learn words from older children which can also be a good or bad thing (laugh). (ECE, Child care site, 1 year)

Yeah, and especially where there is 3 or 4 kids together with different ages, it's almost a lot easier cause they interact together and react to each other. 
The learning is happening even if they don't realize it. Even cooking together, maybe they didn't plan it a week ago, but they were starting to make lunch and then they each did what they could and ....it wasn't planned or premeditated. (Home Visitor, Home Child care, 10 years)

Another benefit stated was the opportunity for children learning English to hear that language modeled by older children. The opportunity to learn language in a multiage setting is quite different than if that child were in a peer grouped childcare and they only heard the modeling of the English language from staff. In multiage groups, children can hear the language from a wider range of competent speakers including preschoolers, school agers and staff. One of the participants shared an example of this;

We have two families, one only speaks Chinese and then M \& R speak, what is it? Punjabi? I'm not sure exactly. We have had over the years. Its interesting how others model English. Yes, look at B, she knows every word and how to spell it. She'll tell the other kids all these words. The peer teaching happens all the time, for sure. (Owner, Child care site, 24 years)

Multiage models of care build a strong sense of community. Children, families, providers and staff, know each other, not in isolated ways, but as a unit. The relationship building takes place even before a child is born as the children wait for the baby's arrival, visit it after its birth, welcomes it to childcare and then offers support and nurturing to the baby and the older sibling.

I find it neat we have some children who are with us a couple of years then moms are expecting. The older children go through the experience of this while in a home and then they go home while mom is on mat leave and then both of them come back to care. It's like you are able to begin a relationship with this baby before they're even here. (Manager, Home child care, 22 years) 


\section{Challenges}

Each participant noted the significant challenges to working in a multiage setting. Among them included the challenge to group activities due to the differing attention spans and cognitive levels. Also, choosing materials presented a problem because of the safety issues involved;

I find the materials challenging for sure for the reason that you have two year olds in the room and you're wanting to put out small pieces that are required for a games that are appropriate for 6 year olds you're worried about choking and stuff. And the little ones like to dump things you know - they're at that toddler stage - they want to dump everything. (Manager, Child care site, 20 years)

There are many challenges working with a multi-age setting. Meeting the needs of the whole group requires a lot more conscious effort than working with a group of children at the same developmental level. (Owner/Operator, $\mathrm{BC}$ Child care site, 4 years)

Another challenge presented by a multiage model was the potential for children of all ages to pick up behaviours, inappropriate for their developmental level. Whether it be the younger children modeling unsafe actions on the climber, or the older children regressing to 'baby talk'.

The way a staff dealt with the challenges of a multiage setting was the most important factor in the success of the model. Participants said it was crucial to be prepared, open-minded and to "go with the flow and multi-task without conscious effort". (Manager, Child care site, 20 years)

\section{Development of a Professional Philosophy}

\section{Intention}

With the exception of the ECE from British Columbia whose reason for entering into a multiage model was very purposeful and intentional, each of the Ontario participants felt they 
started working in multiage settings strictly by coincidence and that they learned the job as they went.

The two owners of multiage settings had very different reasons for opening multiage centres. The Ontario owner structured her centre as a multiage setting not because it coincided with her personal philosophy, but largely because of restrictions in the Day Nurseries Act around physical space. In contrast, the owner from British Columbia was purposeful and intentional in opening a multiage centre after research and additional training.

\section{Reflection}

Participants identified self-reflection as a key component in developing a professional philosophy and seeing the benefits of multiage settings.

consider your philosophy before choosing multi-age. If you are free play based, it works great. If you are curriculum and academic based, there will be greater challenges and it may not be the right setting for your program.

(Owner/Operator BC Childcare site, 4 years)

Reflection also occurred when staff came together to share their own thoughts, feelings, and suggestions on their own work. Particularly when there was a wide range of years of experience among staff, each person was able to bring something valuable to the discussion, whether it be experience or a fresh perspective from a recent graduate. The sharing of perspectives was an important piece of developing one's own philosophy. A participant of 20 years experience notes;

It's interesting because I should let you speak to A. because she just started here. I was actually interested myself in asking her what the differences are and what she had found about how she feels in this type of setting compared to what she was doing. It's a great chance to reflect. I don't really think about what I'm doing I really just do it, but it would be interesting to see if from her perspective. I don't even realize what it all entails. When you do it 
for so long, you don't even know what you do. (Manger, Childcare site, 20 years)

This reflection is constant and on-going and changes as the needs of the community in which they worked changed.

Open-mindedness was another key factor in developing a professional philosophy. This was important for dealing with the day to day operation of the program, seeing as the varying ages required staff to be flexible in their expectations.

If we are all together as a group doing circle, that's another thing that's quite challenging, finding material that is appropriate, from a cognitive perspective and also attention span, like a 2 year old to a 6 year old there at the same time, it's challenging... Yes, it's not a long time of the day, but it's about finding the right material and making it go quickly enough that you're going to keep them interested. (Manager, Child care site, 20 years)

Open mindedness was important in not having preconceived ideas about whether or not the model was theoretically effective, but whether it was good practice.

...but your expectations should adjust so that it's something you can still work with it and adapt the environment. (Home visitor, Home child care, 10 years)

Yes, you think about it, if something isn't working we change it and make it better. You have to stay open minded to the routine and as long as we do what we are supposed to do within the guidelines then its okay, just be flexible. I think multiage requires a lot of open-mindedness (Laugh). (Owner, Childcare site, 24 years)

Each participant reflected on their own families and what worked for them growing up or raising their own children, as contributors to developing their own philosophy. Their lived experience in both their personal and professional lives acted as a reference point for quality. 
Parents don't care about the learning that gets posted on the program plan, they just care that it's happen. I mean when I grew up, my parents weren't educators, they didn't plan it all out, but I still learned. Even when I'd play Barbies with my dad he'd want to teach something all the time like 'do you know how the arms are connected to this body' (laugh) and all this stuff but I'd tell him, 'I don't care, just play with me'. There was teaching. As long as you speak to your children every day there is learning. Go for a walk and have a normal conversation about what you see. You don't realize you're teaching without 'teaching' and I think parents realize that $\mathrm{b} / \mathrm{c}$ kids will still come home and say 'I did this and learned this' with their provider. They learned - even without a program plan (laugh). I think parents are concerned when their child says 'I watched t.v. all day', but when they say 'look what I did or what I made', parents are happy b/c they saw that. (Home Visitor, Home Childcare, 10 years)

After reviewing their narratives, participants were contacted to answer two questions: 1 .How did your narrative help inform your practice? 2. Did you choose to share your narrative with others and what were the results? The answers helped show how important the narratives were in developing their practice.

It's really funny, because I never thought about it until you asked. I've always just done what I felt was right, made the changes if something wasn't working and went on from there. When I see it put down on paper, it helps me think about why I'm doing what I do. It wasn't really my choice to work in a multiage setting, but I think now I know why I do it. (Owner, Childcare site, 24 years).

I always wanted to work in a multiage setting because I knew it worked. It was cool to see that not everyone knew about it before they started working. We shared our stories after you left and it was amazing to see how different each of our journeys were. I think people are more informed now...I think. (ECE, childcare site, 1 year)

It wasn't until my own children started coming here that I realized how much this model is like my own family. It makes it easier for me to know how to respond. My work isn't that different from my life and that's really comforting. I know how to explain it better to parents now too, because I am a parent and even though I'm a teacher, I kind of feel like I can model my work after my own parenting skills and it feels right. (Manager, childcare site 20 years) 
The narratives served as a tool for the organization to get together as a whole and reflect on their experience, their belief and their intentions for the children and families they serve.

After you sent us our narratives, we used them in our next staff meeting. It helped us focus on what the positive points were and what we still needed to work on. I think because I've been here so long they all expected me to have it figured out. When I said I was still making changes based on my experience, it kind of let everyone else off the hook (laugh). They admitted they also have to think about how to solve a problem or what they would do in a similar situation for the next time. It's not set in stone and its okay to keep learning. (Manager, childcare site, 20 years)

The other staff you interviewed let me read her story too. We switched. I found it so helpful to see where she was coming from. I think it has taught me a lot about how to help my staff. She had some really good ideas in there, letting me know what I can do to help her. I wonder if other staff would be willing to discuss it too. I'll bet most of the new staff have similar questions. I've been doing this for more than 20 years and I forget what it's like to be new and not know the answers. I could learn a lot from them too. I wish I had some of the training they had, but I think, at this point, we can help each other. (Manager, Home child care, 22 years)

Participants indicated their professional philosophy had been altered by work in a multiage setting. The process of this change involved many components, continued over time and continues to be altered with each new lived experience. 


\section{Discussion}

\section{The Process of Philosophical Development}

The narratives show the participants' philosophical development beginning with their formal education, changing once they began work in the field and continuing to develop across time through reflection with self and others.

A portion of their development occurred as a result of sharing their narratives with the researcher and colleagues. Participants were eager to share their stories, to hear the stories of others, and to continue sharing this information long after the research was completed. They identified the telling of their story as central to becoming aware of their thoughts and feelings on multiage settings. The narrative allowed the opportunity to pause and gather their experiences, beliefs and perceived values gained and examine them for themselves (Conle, 2003). Through reflection, participants' practice becomes more purposeful, strengths develop and as a result a personal philosophy deepens, supported by lived evidence. There is a shift from a focus on general information toward the personal and particular, which in turn opens the way for understanding alternative ways of knowing and doing (Clandinin, 2007).

The narratives assisted them in being meaningful in sharing their advice with new staff entering the field and in turn learning from the colleagues trained in a multiage model. The narratives of staff can be a starting point from which professional development with new staff can occur. The narrative can be used as a teaching tool for working professionals and preservice early childhood education students to understand the uniqueness of a multiage setting and its differences from standard models. The rich narratives can serve to bring the theoretical model of multiage settings into a lived experience for students. It is the intention that students see the 
model as being relevant to family's lives and to perhaps serve as a reflection of their own future work in the field.

Through this process of story telling there is a change in viewing the multiage model not only as form of curriculum and theory but as an observation of life in practice. Conle (2003) states the connection between teachers, subject matter and social contexts, at first, appear as separate entities. Through the practice of narratives however these can all be grasped together and "become more complex; but they also potentially become more personally meaningful and socially relevant. Curricular complexity and meaningfulness result from connections to life and quest-like inquiry experiences"(Conle, 2003, p. 7). The participants in the study listed some of the benefits of a multiage setting as the opportunity for bonding, nurturing and the sense of community building, all qualities of a caring family model described by Noddings (2002). They noted that the narratives helped them realize the similarities of a multiage model to the way they raised their own children. In each narrative the participants were able to make analogies between children's home life and its relation to a multiage setting. This identification supports Conle's (2003) theory that the narrative allows people to bring meaning into their experience. The model of multiage groupings does support the needs of some families and is a quality alternative to peer grouped care.

The Ontario child care operator and British Columbia operator's intentions for setting up a multiage childcare model were very different. The British Columbia operator was wellinformed and educated about a multiage model and as a result was intentional and purposeful in structuring her childcare in this manner. Her interview responses noted the benefits and challenges of operating a multiage setting. She opened a multiage model because it was a good compliment to her educational philosophy. 
In contrast, the Ontario child care operator ran a multiage model as a result of limitations on the physical space. In the first interview she stated 'she just makes it work', but upon review of her transcriptions she noted she was better able to identify what elements comprised a good multiage model. She expressed interest in continuing to develop this amongst herself and her staff.

Another key component identified in the development of their professional philosophy was peer support. During their interviews, the majority of respondents noted the importance of dialoguing about their practice with their peers. Whether it was with a supervisor or colleague, participants emphasized the importance of reflecting on their work with other professionals. For many, the narratives acted as a starting point from which further discussions with staff could occur. This self reflection allowed them the opportunity to identify their own strengths and weaknesses. It also helped them focus on the perceived benefits and challenges of working in a multiage setting. From this self identification, further development could occur for the group as a whole.

\section{Appreciation of the Uniqueness of Multiage Setting}

Participants' reflection helped to identify the unique qualities of a multiage setting for staff, children and families. Most began work in the multiage setting with the expectation that it was similar or at least comparable to work they had had in peer-grouped childcare, however, upon reflection they realized this assumption to be untrue. Multiage settings are a unique model of care, which require its own specific training. It is not enough to learn the individual components of curriculum and development for each developmental stage and try to piece it 
together in a multiage model. It is not the same as simply putting together the puzzle pieces of what makes a quality peer group setting and expect to build a quality multiage model.

As a result of working with children of varying developmental levels, issues around behaviour management, programming, and physical space require educators to be more conscious of their actions. Staff felt their daily practice needed to be intentional and preplanned, but also needed to allow for open-mindedness based on the needs of the children. They felt a strong need to rely on each other daily to ensure quality care. Group reflection was an important component for staff to continuously review their practice and to make necessary modifications to their work.

For some children, it is a unique opportunity to be in a care setting with siblings, or to experience the role of siblings for single-children families. Unlike a peer-grouped model, in multiage settings children are able to role model for younger or less experienced children. They are able to take on the role of nurturer and inadvertently the role of peer teacher or mentor to younger children. Younger children are able to model the behaviours of older children, mirror . language development and be nurtured by siblings or peers. In drawing parallels to the literature this acts as diminishing the power issues in peer grouped settings and "instead create a community of learners where each has shared roles, power, responsibility, and right to discourse" (Pacini-Ketchabaw \& Pence, p. 8). The research shows there was a change in power issues. There was a change from staff to staff as each member was able to share their perspectives with their colleagues and be valued for it. The power issue around staff to children is altered as children take on shared responsibility of learning. Finally the power relationship between children was altered as each is valued for their own strengths and skills and not recognized for 
their deficits. What was not mentioned was any change in the power relationship among parents to teacher.

The narratives supported Corson \& Martin (2000) findings which suggest the use of multiage models to address the needs of families in the changing cultural fabric in Canada. "Advocates for effective education with diverse populations have become involved in promoting multi-age settings because they are thought to be congenial to family atmosphere and language and cultural preservation" (p. 9). First languages are supported by having siblings together in a room. In addition, children are better able to learn English from a variety of aged peers.

\section{Integration of Family Model in Centre-based care.}

Multiage child care centres operate on the model of a family, with two or three adults providing long term care and children of all ages and stages together. Multiage care allows for the flexibility of routine and structure based on the children's interests, attention span and needs of the group at the time. The focus is much more on building a cohesive community unit which supports individual development rather than the individual pursuits of self development. A multiage model of care is a quality alternative for supporting the needs of some families.

Novick (1996) discusses the importance of moving away from child care grouped by age since "children live increasingly in an age-segregated society, in child care and schools and spend less time with families and in neighborhoods, which include a range of ages" (p. 4). Multiage centres can offer the opportunity for teachers, parents and children the benefits of building relationships. In peer grouped settings, children move through the centre as they age chronologically, changing teachers and classmates with the focus on the individuals in the peer group. In multiage settings children see little of this change, like a family unit they remain with 
the same adults and children for many years. This relationship building allows children to develop attachments to others, work out relationship issues and build a sense of community, learning as they work together as a group towards shared goals and individual development.

Families can experience many benefits from a multiage model. Parents are able to have their children in the same classroom, offering each other support and caring. Families are able to build long term relationships with staff and other families in the setting, helping them feel as though they belong to a community. "Creating a community of learners, in which all members see themselves as both teachers and learners, enables children, teachers, and families to develop shared understanding about what is important to know and why it is important" (Novick, 1996, p. 5).

A multiage model allows for a shared power dynamic between parents and teachers. Viewing learning as a collaborative community approach diminishes the power of any one single group. This sense of community is invaluable in providing informal support to families, which can reduce the stress of raising a family.

The long-term relationships developed in a multiage model can allow children to gain the benefits including supporting each other emotionally, physically and mentally, while creating goals and a cultural framework which is mutually beneficial to all members.

Staff benefit from the long-term relationship building as they watch the children grow: and develop over many stages of their lives. The attachment they experience makes it easier for staff to guide children since they have a foundation of trust. At the core of this trust is the absence of any one group's power over another. Staff does not hold power over children or families, they create a shared power alongside them. The years spent together offer a rich insight into the personalities and learning styles of the children and as a result, they are better able to 
support their development. As a result of building bonds with families over a long period of time, staff members become unique long term supports for the families, a relationship that can continue even after the children are no longer in care.

\section{Post modern view of Education}

Multiage settings reflect the postmodern view of education as evidenced in issues surrounding plurality, the definition of knowledge and the recognition of competencies.

Plurality is witnessed in multiage settings as individuals are less concerned about who of their peers can or cannot perform a task, and more focused on the various ways a task can be completed (Aina, 2000). There is an appreciation of one's unique learning style which is not measured against the style of another, but valued for its own unique quality. This research supports the value of plurality and variation in learning as children both model and observe various ways of accomplishing a task. Children may be able to demonstrate a skill while assisting younger children who may not be observed were the child in a peer grouped setting. Allowing the older child to demonstrate a skill or concept as opposed to simply explaining it, allows for diverse learning.

In a multiage setting, the definition of knowledge is not confined to a cognitive pursuit, but instead broadens the perspective of learning to include: building emotional capacities in caring for others; social intelligences in supporting people at their level of need and: co-operative learning in working together to solve problems and to build on alternative ways of thinking. Gerard (2005) states "the construction of knowledge is a social endeavor. For children, learning and academic achievement is done together" (p. 246). 
The post modern view in multiage settings recognizes everyone as competent. From the staff, to the children, to the families, each is recognized for their own talents, style of learning and coping methods which in and of itself make a person complete. The teachers do not make the children competent through instruction, instead the multiage teacher allows children to demonstrate their own competencies and the teacher builds upon it. "Creating a community of learners, in which all members see themselves as both teachers and learners, enables children, teachers, and families to develop shared understanding about what is important to know and why it is important" (Novick, 1996, p. 5). Children support each other's learning through the modeling, nurturing, and peer-based learning.

Multiage settings reflect the changes of a post modern view by valuing many ways to be right, to thrive as an individual and to grow as a community. Our colleges, universities and training facilities are better preparing ECEs for work in a post modern world. More models of multiage settings than ever before are being operated in Ontario: The creation of Ontario Early Years Centres, the increased awareness of family support practice, and the introduction of multiage settings to college curriculum is a reflection of the acceptance and valuing of multiage settings.

\section{Limitations of the study}

The sample size of the study is quite small and therefore was a limitation. Centres operating in Ontario under a multiage model were scarce and difficult to find. As a result, the original search for multiage childcare settings in Ontario was expanded to include home child care agencies working with multiage models. The search was also extended geographically to 
include Western Canada where a multiage model is much more prevalent due to changes to British Columbia's legislation in 2007.

Another limitation of the study is the researcher's potential biases. Since the researcher's own education and work experience has centred on multiage settings, my biases for the model may come through my interpretation of the data.

\section{Future Research}

Through the identification of themes in this research, future research pursuits have become evident. They are as follows:

1. To undergo an examination of the early childhood education curriculum at Ontario colleges and universities looking at the changes that may have occurred over the past few years. The examination would allow us to know what changes educational institutions have made to reflect the changing field and the existence of alternative models such as multiage settings. In addition, it might assist us in knowing how students feel about their preparedness in understanding and working in a variety of ECE models other than standard, peer-grouped childcare.

2.To further examine the difference in legislation regarding multiage centres in Ontario and British Columbia. Trying to identify what may be impacting on the delivery of multiage childcare in both provinces, its funding sources and its perceived support for families could offer a richer insight.

3. To explore how multiage settings may alter the role of power relations between parents and teachers. 


\section{Recommendations}

The narratives provide numerous insights into multiage models. They are invaluable in helping identify gaps in training and education, in the role of self-reflective practice in childcare and in the importance of the role of the family in care. The examination of a multiage model may help to identify the needs and goals of a community based approach to care. One recommendation would be for teachers and organizations to be aware of the value of developing narratives as a means to developing a professional philosophy.

Some of the other recommendations identified by participants in the study focused around education and training. A lack of education about multiage groupings was identified as a barrier to working in this model. There was a strong sense that multiage settings warranted their own course within the early childhood education diploma or degree. Participants in the research felt it was not enough to dissect the programming and curriculum information provided in the courses around each developmental stage. They felt there were enough unique qualities of multiage settings, particularly programming, behaviour management and room set up, which warranted a separate unit of study.

After working in the field of multiage care, professionals were interested in seeing ongoing training opportunities that would assist them in their work. They felt the workshops offered for childcare professionals centred exclusively on peer-grouped settings and did not address the needs of their work with a variety of aged children.

One participant recommended the College of ECE look into this type of specific training. Seeing as there are so few professionals working with multiage settings, but their need to connect was strongly identified, another recommendation would be to create an organization where they can formally and informally connect and provide support for each other. 
A final recommendation was for employers and or managers of multiage settings, to schedule time for staff to do both individual and group reflection work since participants noted it to be critical to their own professional development. The sharing of meaning is one of the most : critical pieces to a successful multiage framework. The researcher hopes this research will assist ECEs already working in the field with understanding the steps involved in developing their personal philosophy. 


\section{The Narratives}

"Annie"

Originally, Annie trained and worked as a nurse in Ontario but after 20 years in the field she was ready for a career change. She knew she always wanted to work with people and she particularly loved children and so in 1986 she opened her own childcare centre. At the time she didn't know much about childcare and knew nothing about a multiage model of care, but she just knew it would work.

The building Annie purchased for the childcare was one large rectangular room with no divisions. As a result of the physical space, the centre was only allowed to operate as a multiage centre. Since there was no opportunity for separate sleep rooms for infants, or separate spaces for other ages, Annie was licensed to provide care for children ages 2 to 6 years of age, in an all day setting.

Seeing as though childcare as a whole was new to Annie, she was uninhibited by any potential obstacles that may have been presented by a multiage framework. "I never gave it any thought, I just thought it would work. I was positive about it. If you want something to work, then it will work, that's just how I figured it. You just make it happen."

The centre has been in operation for nearly 25 years and still Annie approaches the unique challenges of multiage childcare all in stride. Abiding by her own philosophy, that if you want it to work, it will work, Annie says her perspective of multiage care has not changed very much over time. When asked about her ability to identify what makes the model work she simply states that if changes need to be made, then they are made until it runs more smoothly. The key to providing good quality multiage care is to stay open minded. This means being . flexible in the routine, in your expectations of the children and in your ability to work as a team. 
Although parents are not always aware of what a multiage model is, they do embrace it after they have been coming to her centre for a while. Once they see the model in action they love to see the peer teaching that happens, the nurturing that occurs and the pride children take in them self by being able to assist others. Initially, parents come to the centre out of need, not because of a desire to have their children in multiage groupings. They do like the family style setting though and that's what keeps them coming to the centre for such a long time. She finds it much easier for younger siblings to come to care when they know they will be in the same room as an older brother or sister. Annie laughs as she says "there does come a time for the older children when it's just time to go". Having been with her and her staff for almost five years, she recognizes that children do grow up and become too mature for a setting with 2 year olds. It is a natural progression and certainly there is nothing wrong with them wanting to move on, but the time does come. Annie reveals in the relationships that get formed over time and she is proud to have had a hand in getting older children to a place where they are developmentally ready to move on.

She credits the centre's longevity to her team of staff members. The director of the centre has been employed there for almost 20 years and for nearly 15 years of that time, there were no staffing changes. All four members of the team worked together until they "just clicked". Annie says they simply had to look at each other and they knew what to do. They worked so well together and that, Annie felt, was the difference in her centre's success in supporting the community all these years.

Since that time new staff have started and have each remained there for 5 or more years. As an owner/operator, Annie is incredibly proud of this as she feels the relationship built over time amongst staff, children and families is critical for everyone's benefit. 
Annie believes hands-on job training is the only way to become comfortable with working in a multiage setting. She feels strongly that the profession of ECE needs to take a vested interest in on-going training and re-training for its working members. She uses the comparison to the certification courses required of nurses during her career in the medical field. Early childhood education, Annie believes, is equally as important a field and staff need to be up to date on the most current models of care and best practices.

It is only through on going training and support that our industry can remain current and supportive of the changing needs of families. 


\section{"Belinda"}

Belinda graduated with her diploma in early childhood education from an Ontario college in 1999 and began working at a peer-grouped child care setting right away. She returned to school and completed her university degree in Psychology at the same time as working a full time job. Over the next 10 years Belinda gained rich experience working in the field in a variety of settings including child care, preschool, private school and tutoring.

While working at a childcare centre, Belinda was anxious to increase her breadth of experience in the field and began looking at alternative models of care. Through discussion with colleagues she learned about home child care and the role of an ECE as home visitor. Among other things, the role of a home visitor is to offer help or assistance on things like behaviour management, programming, and room set up, communication skills, and professional behaviours to the providers working with the children. Through a series of monthly visits, training workshops and phone support services, home visitors are able to address the needs of providers and families registered with the agency.

Belinda believed she could use her previous experience from child care to become an effective, supportive home visitor for the providers who perhaps did not share her experience or formal education. Through her network of contacts, Belinda became aware of the job opportunity with a local home childcare agency and applied for the position.

Even after applying for the job Belinda admitted she knew little about home childcare. “A long time ago, I might have seen an ad, but I didn't really know much about it. I knew it existed, but I didn't know what it was. It was a bit nerve-wracking when I started."

Just six months ago Belinda began her work as a home visitor supporting providers working in a multiage model of childcare. In this short time frame her perspectives on home 
care and the multiage model has changed drastically. Upon beginning her job, Belinda wasn't sure what to expect from the home childcare noting that most providers lacked formal education and some struggled with their own English. Reflecting upon her work now she admits she was surprised at the effectiveness of the model. She was pleasantly surprised at how much more care and attention is given to children. She felt the model was better because providers could be much more spontaneous in planning. When children come up with an idea, the provider is able to "run with it" and expand on the children's interests in a way that supports all types of learners. Her experience in centre care did not allow for this flexibility and Belinda felt that was an unfortunate and a great loss for the children.

She believes her strength in programming to be her greatest asset and prides herself on being able to share quality, inexpensive ideas that are appropriate for all age groups. Although aware of the safety concerns when programming for multiage groups, Belinda does not see them as a barrier to providing excellent opportunities: "It's like painting, they all like to do it, but it doesn't have to cost anything. I mean, just fill up a bucket of water and get brushes and go up to the back of your fence and yeah, it gets darker and then the sun dries it up."

In developing her repertoire of appropriate activities, Belinda credits the colleagues she has worked with in the past and their ideas. Ever since she began work in childcare she has taken keen interest in gathering programming ideas that she's seen work. When it came time to support the providers in their programming, she simply referenced things she had seen work.

Belinda didn't have to educate the providers on programming as much as she needed to just support them. She found often times the providers were already programming for multiage groups very effectively, they just didn't consciously know that they were. Her role was more 
about encouraging them and pointing out what it is that they do that really works. Her role as it turned out was about building others self-efficacy.

Another part of Belinda's role involves informing new parents about the multiage home child care model as well as supporting existing parents within the agency. Like herself in the beginning, Belinda finds most parents to be completely unfamiliar with multiage settings and home child care in general. She believes we are doing a disservice to parents by not informing them of their options for care. Belinda feels that perhaps the newly formed College of ECEs could take on public education as one of its mandates: In addition to public awareness, she would like to see on-going training provided for ECEs. Although she is aware training opportunities exist, she feels the industry needs to do a better job in getting the word out to professionals.

Belinda believes the placements students are given during their education act as big factors contributing to their view of the field of ECE in general. She felt very lucky to have had quality placements, but she knew of a large number of students who graduated with her but chose to never work in the field as a result of their negative placement experience:

In addition, she believes it is the colleges' and universities' responsibility to inform students of their options upon graduation, including the option of working in home child care, multiage centres, early years centres, private schools and other frameworks of interest. Referring again to some of her class mates, Belinda conveys that they felt like they had no option other than child care and chose not to go into the field. Perhaps if they were made of aware of the options, she believes, the industry would not have lost creative, competent, individuals. 
Having said that, Belinda recognizes the training for ECEs has changed over the past 10 years since her graduation. She is hopeful for the industry as she recounts a friend who had recently graduated from ECE and received specific training in administration for the ECE field.

Her experience working in home childcare has made Belinda feel excited about the new challenges she faces. She feels it has broadened her professional philosophy as she is able to reflect on her own upbringing and compare it to the model of quality home childcare. Her ideas around how learning takes place have been altered away from pre-planned, structured, centrebased care to more of a play-based philosophy that embraces the informal nature of learning. She likens it to her own experience growing up.

In her dialogues with parents, Belinda has come to see that this informal nature is what parents are looking for in home childcare for their own children. "I think parents are usually just happy with a safe and nurturing environment. Considering most of our children are 2 and under or 3 and under, they don't care about out of this world programming, they just want their kids to be safe and happy. And I mean they are still learning, whether you put a program plan up or not, they're still learning. They go to the park or out to a picnic or to a pond to see ducks, they're still doing so many things, they're learning so many things, what they may not be good at is preplanning the learning or writing it down, but they're doing it, they're learning. Parents don't care about the learning that gets posted on the program plan, they just care that it's happen.". Belinda admits that her professional perspective has been greatly altered as a result of her work in home childcare and recognizes that it will continue to change as she continues to gain experience in the field. 


\section{"Elise"}

Elise completed her B.A. in Sociology at an Ontario University almost 20 years ago. She knew she always wanted to work with children and had originally planned to continue her studies and become a school teacher. She married and soon after both she and her husband lost their jobs, forcing her to seek employment and put off going to teacher's college. She was given accreditation to begin working full-time in childcare as she pursued her Early Childhood Education part-time at a community college. The centre Elise came to work at 20 years ago was a multiage setting, where children ages 2 to 6 years were all in care in the same room at the same time. Unfamiliar with childcare at the time, Elise did not realize how unique a model of this nature was and she simply learned the duties and subtleties of her work through hands-on experience. Elise gained her diploma in E.C.E. some years later and continued to develop her skills and mentor other professionals, as she remained in the same multiage setting for over 20 years.

The centre, as Elise explains, has always been licensed under the Day Nurseries Act to be a multiage setting because of the physical space restrictions. It is one large rectangular room filled with approximately 24 children spanning five years difference in age. While there have been times the centre has tried to divide the children up by age, Elise notes that it is changed back and forth based on enrollment and the needs of the children in care at the time. Elise's reason for working in a multiage setting was more of a coincidence than an intentional desire, and she is quick to note there are both great benefits and legitimate challenges involved for both children and staff.

Elise sees one of the benefits of multiage settings as the opportunity for older children to act as role models and nurture the younger children. "I think probably the biggest benefit is the 
older kids really take on the role of the nurturing. They love to help the little ones and that makes them feel really important." This type of care shown between children is something she sees on a regular basis. Older children like to assist each other at the craft table or model good manners in order to present themselves as role models to the younger children. Some times the peer teaching happens in a more indirect and unintentional way as the younger children gain skills such as language development just by being in the midst of older children.

Having multiage groupings in a centre is not always an easy experience for everyone according to Elise, as all behaviours modeled and often copied, are not necessarily positive behaviours. After nearly 20 years of working in the same centre Elise is able to identify many more challenges she finds in the multiage model than when she first began teaching, such as differences in attention span, modeling inappropriate behaviour to younger children and the need for older children to have their own private space during the day. She believes a peer grouped child care would be much less stressful, but then she admits she would miss the relationship building she gets to experience in a multiage setting.

Most of the children in the childcare stay in the same setting from age 2 to 6 years for a span of 5 years. While the benefits do exist for children and families, Elise says they come to a point where they are mentally ready to move on to school.

The work in a multiage setting is very challenging and requires staff to be well prepared and to be very open-minded to a model whose expectations may change each day.

Elise believes multiage settings have helped to support the families in the community. From being able to have siblings in the same room together, to only children in a family experiencing what it is like to have siblings, to families learning to speak English along side their sibling in the same room, the model has been great at creating a comfortable setting for families.: 
Like herself at the beginning of her work in multiage settings, Elise says the parents coming to their centre are not at all familiar with a multiage model. They do not come seeking it out; they are simply looking for quality care, but after a time "they just fall in love with it".

Seeing as though Elise began work in childcare before she had received any formal training, she accounts for most of her professional development in the field as due to hands-on training. Even after her schooling was completed, she did not receive any training on the specifics of work in a multiage setting. She felt her training was more "compartmentalized, no one put it all together" and that it was a "real test of your skills in a multiage setting all at oncebehaviour, curriculum, all of it" was to be tested. Although she did not feel technically prepared, it was the only model she ever worked in and therefore felt comfortable in her own skills.

It was when her own children began to attend the centre that Elise's perspective of multiage settings broadened and she began to see how natural the model was. Having her two children in the setting at work with her helped Elise to realize how close to a model of a family this group of people resembled and acted like. Over time Elise was able to see how unique it was to have siblings, her own and other sets, in care together. She noticed siblings would comfort each other at times of need, instead of seeking care from an adult staff. They played together for the majority of the day and the children were not focused on the age of their playmate, but more of a relation interest.

Elise's development as a professional in multiage settings continues even today. She is interested not only in additional training that might support her learning, but also her interest to know the stories and experiences with other staff who have worked in peer grouped child care. By sharing her story and hearing the story of others, Elise is continuously evolving as she is ${ }^{-}$ 
better able to identify what makes her work unique. Seeing as though a multiage setting "all that she's known", Elise takes pleasure in reviewing the stories of other staff who've worked in a peer grouped centre and to understand all of the things she does that are out of the ordinary. The sharing of stories is helping her to see all that she does without even considering it. 


\section{"Jessica"}

By her own admission Jessica ended up working in a multiage setting purely "by fluke".

"I wasn't looking to work in child care. I was looking for my own children and I called and by fluke it came up that I was an E.C.E and they said they were hiring. They asked what I was doing. They asked if I knew anything about home care and I knew the name but I knew nothing about it so I came in and the next month I started my visits. There was no ...it was on the job training (laugh) and then it was off you go... you get your reports and ... well, off you go.

Jessica works for a home childcare agency in southern Ontario. She began working part time as a home visitor and before she was hired full time as a manager. Being a home visitor your role is to offer help or assistance on things like behaviour management, programming, room set up, communication skills, and professional behaviours to the providers working with the children. For the past 12 years as a manager, Jessica has been responsible for supervising all of the home visitors, providing support and education to the home child care providers, developing relationships with parents and acting as an overall support to the agency. The homes, which are licensed under the DNA through the agency, operate as multiage settings. One provider cares for a maximum of five children under the age of six, in her home. The DNA specifies homes have no more than three children under age three and the remaining two may be ages three and older. As Jessica notes, when you factor in the providers own children who are not factored into the ratio after age six, some of whom may already be teenagers, you can have an age range of almost 18 years.

She received her formal training over 20 years ago, graduating from an Ontario college with her diploma in early childhood education. This training she felt, although excellent for centre based care, really did not prepare her in any way to work in a multiage setting. "I think it 
was at school age when we got into all the diff types of theories and we had to visit different types of settings and so I went to an alternative type of school and that was an eye- opening experience. It wasn't childcare age, but it started at pre-school and went up to high school. It was really, really interesting and I thought 'why are we not doing more on this'? I think there is a lot that would benefit all students to see what is out there and that there are choices." When it came to working in a multiage setting Jessica felt 'ignorant' about the whole scope of home childcare. It was a definite learning curve for her over the first year.

The benefits of home childcare and a multiage model were not always obvious to Jessica, especially when she first started. She felt it challenging to come from work in centre based care to someone's home. She felt she was "picky" about quality care and now saw home care as operated by women, largely untrained with little formal education, who used mainly their experience with their own children as a basis for running their program. She was unsure of the standards in the beginning because it "didn't make sense with the experience I had had in centres". At first she had almost a negative opinion of it because she couldn't see the benefits. She felt the kids in these homes were being given basic care. It wasn't until she saw the benefits how much kids have grown and developed that her perspective began to change. "I had to get rid of the centre snobbish side of me and say 'you have to embrace it'. It was neat but it was so foreign, I was totally unprepared."

Jessica's experience as an ECE in home childcare was so different from centre based care. She realized you need to focus on issues that would never have come up before in centre based care like safety issues, choking, and appropriate developmental toys for all the ages. Also personalities of the families and children were critical to the success of the model. Since home 
care is such an intimate setting of only five children and one adult, all in a home, Jessica says getting complimentary personalities together is key to the success of the model.

As part of her managerial role, Jessica supports the home visitors who visit the provider's home each month. The visitor's perspectives vary greatly from person to person, but she finds each of them present her with questions or queries about why something is or is not allowed in centre based care, but it is the opposite in home childcare. She feels the quality of the home visitor and their potential for support is directly related to the amount of interest the visitor takes in her job. In order to be effective, Jessica feels home visitors need to question things they see, seek support from other staff and keep an open mind about the value of the model.

In order for the providers to be successful in the model, it is important they are thoughtful and purposeful in the structure of their program. You must constantly adapt the environment to suit their learning needs. You need to have clear expectations around behaviour management issues and you must be invested in building a relationship with the children and families in your care. This relationship is built around mutual trust.

In her experience dealing with parents looking for care for their children, Jessica find parents feel vulnerable about their care. Most parents are so desperate to find care for their children at a place that is convenient and at a price they can afford. The actual model of care, whether it is multiage or peer grouped, is often not important to parents at all. In fact, Jessica tells us most parents are completely unaware of what multiage settings are. Their only concern is the happiness and safety of their child. Especially with homecare she says, "most parents don't' know what they're looking for until they find it. You don't know what's behind that door, even as a parent myself you don't know what you're going to find. You don't what the person is like, what the home is like, what the other children are like. You have no idea." 
The sense that we build communities through home childcare was an obvious benefit of a multiage settings in Jessica's perspective. It has the potential for long term relationship building since a provider may have an individual child in care for over 12 years and with the addition of a sibling, extend the family - provider relationship for $15-20$ years. The relationship is often developed with future siblings even before they are born as the children and the provider await their arrival. They become part of a long-lasting community. This type of relationship does not happen in any other model of care. When it works well, it is a benefit for both the provider and the family.

The proposed changes to the DNA in regards to home childcare offer the possibility of great change in the homes. Jessica supports the proposed change of having two providers in the same home with a maximum of 10 children. This two provider model would offer the providers much needed support, assistance with the daily routine, programming and particularly in the unfortunate case of an emergency. While she agrees with the change to the legislation, she does not think most homes have the physical space to accommodate this change.

Reflecting upon her own experience working the field, Jessica realizes how important the hands-on training was in terms of her professional development. Although you cannot become a home visitor without former childcare experience, Jessica contends there is no other way to prepare for a multiage model other than to experience it first hand. Even though she did not receive training in her course work around multiage models, she believes the only way to learn about its nuances is to work in the field and reflect on what you are seeing. "With two years experience and two years of college, there's nothing really to prepare you for it. You can just talk it out, be there, do the visits yourself and ask questions as you go." 
Over time working in a home based child care agency, Jessica's perspective on multiage care has changed. "I think I put it on an even keel with centre based. You're gonna have great and not so great. I've met enough women who care, who've gotten their eces, who have no formal training but are doing way more than I ever did working in a centre. For me, I recognize it as a valid form of child care; it took me a long time. When I rate the centers I've worked at on a scale, then some of them don't come out as rosy either, so home child care is a really valid form of care in my opinion" 


\section{"Maria"}

Maria has been working in the child care field for 10 years and opened her own centre in July 2006. She had attended university prior to pursuing her ECE and IT training. She completed these programs via distance education.

Her facility is a double licensed Multi-Age and Infant Toddler facility. In November 2007 when the $\mathrm{BC}$ child care licensing regulation went through changes and introduced a MultiAge setting, Maria was eager to pursue this avenue as she was presently operating as a family child care facility. Feeling frustrated with the limitations placed upon me as a family child care provider both at the licensing level and in regards to government funding, the multi-age regulation allowed her to get the recognition she felt she deserved for the training she had received. It also allowed her to become a group child care facility without have the strict 30 months-5years limitation on the ages of the children in her care. Her centre had many infant and toddler children and therefore, prior to this regulation felt unable to expand or grow. The Multi-age setting made a very smooth and comfortable transition from family care to group care in which she now receives recognition for my training as well as greater government funding. All with a wide age range.

In order to assist herself from the change in model, Maria sought out the information on her own. "I simply read the new regulation when it was published. I took a keen interest in this grouping and spoke with my local licensing officer. Initially, I had a better understanding of this grouping than she did so we really worked through it together."

Maria feels there are many benefits to children in differing ages to learn and grow together. She encourages freedom and self-help in my program and believes there is no better setting for this than a multi-age program. "The younger children are eager observers and the 
older children are eager helpers and teachers. I strongly feel that children are their own best teachers and when you can put a group together that can offer so much to each other, it's a very positive experience."

A great joy for her has been this first year of her son's life and introducing him to the children, many of whom were his age when they started in her care. It's been an amazing experience for all of involved and they have developed wonderful bonds.

Also, Maria says she has been able to support families with more than one child which eases a lot of child care stress from families who otherwise would need to organize two separate spaces, drop offs, pick ups, billing, communication etc.

She recognizes also that there are many challenges working with a multi-age setting. Meeting the needs of the whole group requires a lot more conscious effort than working with a group of children at the same developmental level. She runs a free play based program so although there is minimal formal structure, ensuring each child or group of similarly aged children is having their needs met and being challenged at their own level of ability and development is challenging. She finds that the challenges change in intensity depending on the number of infants and young children in care. For example, it is quite easy to tend to a diapering/bottle feeding child within the flow of your regular day. However, if you have more than one child requiring such one on one care, the challenge increases. It's really about accepting children in ages that work for you and for the other children in your care.

Maria feels he differences for the children in a multi-age grouping vs. a peer-grouped room are endless. "I personally feel that there is a lot more empathy, caring, compassion, patience, tolerance and understanding in a multi-age setting. That said, I also feel that there is more frustration for the older children. However, the educator in me feels that this is going to 
benefit the children in their futures. They will often meet people that step on their toes, bite them, destroy their projects, and require attention from others in their lives. They are learning valuable problem solving, coping, and empathy skills."

Socially, Maria has found there are many benefits as well. Often in a peer-grouped setting the children are told that "everyone can play" and to "include all of their friends." In a multi-age setting, the children seek out playmates on their own. They are naturally drawn to children who share their interests and who they feel they have things in common with. They are taught to have respect for the older or younger children, but are not forced to be their playmate.

The older children obtain so much from being a "teacher". They are more aware of their actions and very proud to be involved in milestones reached by younger children. When her son began walking, they cheered, "We taught him that! He watched us! We showed him!"

Her staff still finds it challenging to work within a multi-age setting. It takes a patient, calm, relaxed individual who can go with the flow and multi-task without conscious effort. Meeting differing needs presents challenges and the best way to make a multi-age setting work is to ensure the older children have the opportunity to have space that does not need to be shared with the infant/toddlers and to involve them in the care and talk to them about why the babies need your care and attention. Despite the challenges, she believes a huge benefit for the staff is having the same children and families in care for many years - a real bond and connection is formed.

If she were to choose an ideal model of care, it would be comprised of a part time multiage and part time peer group setting. A setting in which the older and younger groups were together for meals, outside play, story and music time etc. but also had separate play areas and activities that met their developmental needs. 
To continue the learning experience for herself and her staff Maria would like to see additional training offered centering on meeting the differing needs of children throughout each day. She believes her staff would benefit from training in programming for multiage settings that draw children's interest and encourage growth in the whole group together as a unit. The aspect of community building is critical to the success of a multiage framework.

Perhaps more than any training, hands-on experience or continuing education, Maria believes the key to an ECEs success in a multiage setting is to consider your philosophy before choosing multi-age. If you are free play based, it works great. If you are curriculum and academic based, there will be greater challenges and it may not be the right setting for your program. 


\section{“Amanda"}

Amanda graduated with her diploma in Early Childhood Education from an Ontario college just a few short months ago. With the exception of four placements at three different centres through her college training, this was Amanda's first experience working full time in childcare. Each of the models Amanda had been placed at and subsequently did supply work at were all centres that operated under a typical peer grouped framework. The centre where she is currently employed operates under a multiage framework where children ages 2 through 6 years are in the same room together for the entire day.

By her own admission, Amanda felt she was well prepared for work in a multiage setting. She recognized how different the expectations were in a multiage setting versus a peer grouped centre, but still she felt her educational training, life experience and personal philosophy were all key components in making her feel competent and ready to face the varying challenges multiage settings had to offer.

Amanda felt confident in her formal training to be able to work in any type of early : childhood setting. "We were trained in many areas of philosophies and day care centres like Montessori to Reggio, we had it all." Upon beginning work in the multiage centre Amanda felt she had been completely prepared for the environment, "so when I came in I saw basically what we had studied."

This formal training in conjunction with the fact that Amanda grew up watching her mother provide home child care to a wide range of aged children, left her feeling confident in the effectiveness and the possibility for success in a multiage model. Since Amanda was 2 years old, her mother was providing care for up to 5 children at time in their home. This opportunity allowed Amanda to see the multiage model in action and it helped to shape her philosophy about 
the possibility for other models of care. "Oh for sure, I've always had an open mind to every kind of education, but she (mother) definitely modeled a lot of strategies for me....that's why I'm here today."

Upon reflection, Amanda wishes her college provided students more opportunities to do placements in a multiage setting, but the lack of centres operating under this model make it very challenging to do so. Despite her formal training and life experience, she did wish her placements offered her this option.

Having the child care children with her at her home in her early years opened Amanda's perspective to the benefits of multiage models. She felt the range of ages allowed children to become role models for each other and to have the benefits of experiencing sibling-like relationships for an only child. She is able to see the children in her workplace now experience the same types of benefits she received as a result of being with a range of aged children. "I'm thinking of someone in particular, they get to be very caring of the younger ones, they like to help rub their backs and put them to sleep and so they reel they really care for the younger ones." Nurturing others and role modeling behaviours are among the benefits Amanda sees for children in a multiage setting versus a peer grouped setting. The younger children want to build like the older ones or draw like them "which can be good and bad too because you want them to have their own unique way of doing things", but it does provide an opportunity to model.

Working in a multiage model allows Amanda to improve her professional skills by reflecting on her own childhood experience and remembering what worked best for her mother and for the child in her mother's care in assisting the children's growth.

Due to her own personal experience growing up in a multiage model, as well as her recent education in ECE, Amanda is able to share her perspectives with more senior staff and 
thereby create an on-going dialogue for everyone around what makes up best practices. Amanda notes the importance of teamwork in a multiage setting and counts on the opportunity to share her ideas as well as her challenges with her fellow staff members. 
Appendix A

\section{Be part of an important research study on Multi-age Child Care.}

*Do you have a diploma or degree in Early Childhood Education from a registered college or university?

*Are you currently working in a childcare setting which uses a multiage setting?

${ }^{*}$ Have you worked in a multi-age setting for at least 1 year?

*Are you available to be interviewed on two separate occasions outside of working hours, with each interview taking approximately one hour to complete?

If you answered YES to these questions, you may be eligible to participate in a research study.

The purpose of this research study is to gather the experiences of E.C.E.s working in multi-age settings. Participants will receive an incentive payment of $\$ 50$.

This study is being conducted by Jean MacDonald, a Master's student in Early Childhood Studies at Ryerson University. (Faculty Supervisor: Dr. Elaine Frankel)

Please call Jean MacDonald at 647-880-5158 or email at jean.macdonald@nerson.ca for more information. 


\section{Appendix B}

\section{Ryerson University \\ Consent Agreement}

\section{"Narratives as Reflective Practice in multi-age Child Care Settings"}

You are being asked to participate in a research study. Before you give your consent to be a volunteer, it is important that you read the following information and ask as many questions as necessary to be sure you understand what you will be asked to do.

Investigators: My name is Jean MacDonald, B.A., B.A.A. a Master's Student at Ryerson University in the field of Early Childhood Studies. My thesis supervisor is Dr. Elaine Frankel, professor at Ryerson University.

Purpose of the Study: For the purposes of my major research paper, I am conducting a study which examines teacher's reflections on their work in multi-age settings. The study will be conducted with three separate registered early childhood educators each working in a multi-age setting for a minimum of one year.

Description of the Study: The process of your involvement in this study would include two separate interviews with the researcher, each lasting approximately 1 hour in duration at a time and date convenient to you outside of your regular working hours. Each of the two interviews will be audio recorded (with your permission). After each interview you will be provided with a written transcript of your interview for you to review and make any changes necessary. The interviews will centre around your own experience and reflection on working within a multi-age setting, focusing on some of the challenges and benefits, and the possible change in your perspective as and educator.

What is Experimental in this Study: None of the procedures [or questionnaires, if applicable] used in this study is experimental in nature. The only experimental aspect of this study is the gathering of information for the purpose of analysis.

Risks or Discomforts: Gathering personal information can present a discomfort or risk to the participant. Although the information gathered for this study will be reflective in nature, it is important that you be aware of any possible risks. The known risks for participating in this research include negative consequences from a supervisor for stating negative information about the structure or operation of the centre in which you work. Throughout the process, you will be reminded that you are able to stop your participation in the research either temporarily or permanently at any time. You have the right to refuse to answer any of the questions should you feel your answer will jeopardize you in any way. The nature of the questions being asked are open ended and do not at any point request comment on the subject's perspective on how well the centre is operated. As for the participants feeling discomfort about sharing information, this will : be the role of the researcher to minimize this feeling. 
Benefits of the Study: By using the tool of narrative inquiry, the researcher will be asking subjects to reflect upon their own work and the perceived values of nurturing children in a multiage setting. A potential benefit for the subject is that from using this reflective practice, participants will be more meaningful in their behaviours, support services and professional behaviours in the field. Having reflected on your own work educators may be more purposeful in their mentoring of new educators either as staff or student placements. Your reflective practice may help you identify strengths and resources to further your own capacities. It may also help families within the centre as they are able to identify the strengths of a multi-age grouping. It might assist parents in feeling their cultural and ethical values are being actively supporting by hearing the words of the staff. As well there will be a benefit for future ECE students as they use the participant's reflections as the beginning framework for the importance of reflecting on their own practice.

Confidentiality: The researcher and her MRP supervisor will be the only ones to have access to the collected data. All the information collected will be transcribed into the researcher's personal computer. Files with password protection will be used to store this information. Any files being transported via flash drive will also be password protected. The audio recordings will be accessible only by the researcher and her MRP supervisor and will be kept only until they can be transcribed and then will be erased. Any physical transcription of notes will be stored in a file cabinet in the researcher's home office. Any other papers will be shredded for confidentiality. The data, both physical and on computer files will be stored for a minimum of 5 years. For the purpose of confidentiality, all subjects will be assigned factious names. Any access to data would be in keeping with Ryerson's Ethics Board's policy and protocol.

Incentives to Participate: Upon completion of two hour long interviews and review and possible revision of the transcribed interviews, participants will each receive a $\$ 50$ honorarium.

Voluntary Nature of Participation: Participation in this study is voluntary. Your choice of whether or not to participate will not influence your future relations with Ryerson University. If you decide to participate, you are free to withdraw your consent and to stop your participation at any time without penalty or loss of benefits to which you are allowed.

At any particular point in the study, you may refuse to answer any particular question or stop participation altogether.

Questions about the Study: If you have any questions about the research now, please ask. If you have questions later about the research, you may contact.

Jean MacDonald

647-880-5158

If you have questions regarding your rights as a human subject and participant in this study, you may contact the Ryerson University Research Ethics Board for information.

Research Ethics Board

C/o Office of the Vice President, Research and Innovation

Ryerson University 
350 Victoria Street

Toronto, ON M5B 2K3

416-979-5042

\section{Agreement:}

Your signature below indicates that you have read the information in this agreement and have had a chance to ask any questions you have about the study. Your signature also indicates that you agree to be in the study and have been told that you can change your mind and withdraw your consent to participate at any time. You have been given a copy of this agreement.

You have been told that by signing this consent agreement you are not giving up any of your legal rights.

Name of Participant (please print)

Signature of Participant

Date

Name of Investigator (please print)

Signature of Investigator

Date

Agreement to be audio recorded during two separate interviews:

Date 


\section{Appendix C}

\section{Interview guidelines - Interview \# 1}

\section{Filter questions:}

How many years have you been working in the childcare?

From which College/University did you graduate?

Are you familiar with the term "Multi age Groupings" in childcare?

\section{Introduction}

\section{Narrative interview}

Introduction to topic: "I am interested in hearing the stories of teachers working in multi-age settings. I would like to hear about your experience, what prepared you for this type of setting, how your perspectives have developed and perhaps how they have changed over the course of your work.

\section{Length: Approximately 1 hour}

Questions; these questions will be a guideline for conducting the interview.

\section{Staff Narrative:}

1) Tell me your story about working as an ECE within the framework of Multiage groupings.

2) What have been the joys?

3) What have been the challenges?

4) What type of training did you receive either formally or informally which support your understanding of Multiage groupings?

5) Have you worked in childcare settings that are not grouped in a multiage format?

6) What do you feel the differences are for the children in a multiage grouping vs. a peergrouped room?

7) What do you feel the differences are for the families?

8) What do you feel are the differences are for the staff?

9) If you were able to choose the framework you felt children did best in, what would it look like? 


\section{Appendix D}

\section{Interview Guidelines - Interview \#2}

Prior to the second interview, participants will have the opportunity to review their first interview and make any changes, additions or clarifications needed.

Length: Approximately 1 hour

Questions; these questions will be a guideline of conducting the interview,

1) Upon review of the transcription of your first interview, how would you say your perspectives have changed or altered since you began working in a multi-age setting?

2) What do you think may have caused those changes in perspective?

3) If you could share the most important information with future ECEs working in a Multiage = grouping, what would that be?

4) What could the field of Early Childhood Education do to further support you as a staff in a Multiage Setting?

5) What could the field of Early Childhood Education do to further support future students who might work in a multi-age setting? 


\section{References}

Aina, O. (2001). Maximizing learning in early childhood multiage classrooms: Child, teacher, and parent perceptions. Early Childhood Education Journal, 28, 219-224

Ali, M., Corson, P., \& Frankel, E. (2009). Listening to Families. Toronto: Chestnut Publishing.

Beck, C. (1993). Postmodernism, pedagogy, and philosophy of education. Philosophy of Education, 1-18.

Clandinin, J. (2007). Handbook of Narrative Inquiry: Mapping a methodology. London: Sage.

Conle, C. (2003). An anatomy of narrative curricula. Educational Researcher, 32 (3), 3-15.

Corson, P \& Martin, S (2000, April). "Quality: Canadian Style" Paper Presented at the Association of Childhood Education International., (ERIC Document NO: ED 439 839, $1-14$

Evangelou, D (1989). Mixed-Age groups in early childhood education. Urbana IL: Office of Elementary and Early Childhood Education. (ERIC Document No: ED 308990)

Family. (n.d.). Vanier Institute of Family. Retrieved September 1, 2010 from http://www.vifamily.ca/about/definition.html

Friendly, M. \& Rothman, L. \& Oloman, M. (Oct, 1991). Childcare for Canadian Children and Families. Canada's Children: A Priority for the 90's. Paper Presented at Child Welfare League of America/Canada. Retrieved from: www.childcarecanada.org.

Friere, P. (2000). Pedagogy of the oppressed. Brazil: Continuum International Publishing Group.

Gerrard, M. (2005). Bridging the gap: Towards an understanding of young children's thinking in multiage groups. Journal of Research in Childhood Education, 10, 243-250

Gmitrova, V. \& Gmitrov, J. (2003). The impact of teacher-directed and child-directed pretend play on cognitive competence in kindergarten children. Early Childhood Education Journal, 30(4), 241-246

Gonzalez-Mena, J. \& Widmeyer Eyer, D. (2008). Infants, Toddlers and Caregivers. A Curriculum of Respectful, Responsive Care and Education. New York: McGraw Hill Higher Education.

Gusky, T. (2002). Professional development and teacher change. Teachers and teaching: Theory and Practice, 8(3-4), 381-391. 
Hinyard, L. \& Kreuter, M.W. (2007). Using narrative communication as a tool for health behaviour change: A conceptual, theoretical, and empirical overvicw. Health Education and Behaviour, 34(5), 777-792.

Hoffman, J. (2003). Multiage teacher's beliefs and practices. Journal of Research in Childhood Education, 18, 5- 17.

Kasten, W. (1998). One learner, two paradigms: A case study of a special education student in a multiage primary classroom. Reading \& Writing Quarterly, 14, 335-444.

Kolstad, R. \& McFadden, A.(1998). Multiage classrooms: An age-old educational strategy revisited. Journal of Instructional Psychology, 25, 14-21.

Kyle, I. (1994). Cherishing Children, Building Caring Communities. Canadian Association of Family Resource Programs, Ottawa, Ont.

Lubeck, S. (1996). Deconstructing "Child Development Knowledge" and "Teacher Preparation." 2, 147-167.

Ministry of Children and Family Development. (2007, November). 2007 Press Release: New

- Regulation Improves Child Care Opportunities. Retrieved September 14, 2010 from http://www2.news.gov.bc.ca/news releases 2005-2009/2007HEALTH0135-001448

Neuman, W. (2006). Social Research Methods: Qualitative and Quantitative Approach. Toronto: Pearson.

Noddings, N. (1986). Caring: A feminine approach to Ethics \& Moral Education. California: University of California Press.

Noddings, N. (2002). Starting at home: caring and social policy. Califomia: University of California Press.

Novick, R. (1996). Developmentally appropriate and culturally responsive education: Theory in practice. Northwest Regional Educational Laboratory, 1-7.

Pacini-Ketchabaw, V \& Pence, A. (2005). Contextualizing the reconceptualist movement in Canadian early childhood education. Research Connections Canada, 5-16.

Pettit, G. \& Dodge, K. \& Brown, M. (1988). Early family experience, social problem solving patterns and children's social competence. Child Development, 59, 107-120.

Spodek, B. \& Saracho, O. (2006). Handbook of research on the education of young children. Califomia: Routledge. 
Stone, S. (1998). Creating Contexts for Middle-Age Learning. Childhood Education, 74, $234-$ 237.

Tomlison, C. (2004). The Mobius Effect: Addressing learner variance in schools. Journal of Learning Disabilities, 37, 516-524.

Voltz, D. (2003). Personalized Contextual Instruction. Preventing School Failure, 47, 138- 143.

Weibe Berry, R. (2006). Beyond strategies: teachers beliefs and writing instruction in two primary inclusion classrooms. Journal of Learning Disabilities, 39 (1), 11-25

Winsler, A. (2003). Vygotskian perspectives in early childhood education: translating ideas into classroom practice. Early Education and Development, 14(3), 253-270

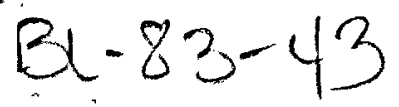

